JBR-D-13-00490

\title{
DOES INCREMENTAL AND RADICAL INNOVATION PERFORMANCE DEPEND ON DIFFERENT TYPES OF KNOWLEDGE ACCUMULATION CAPABILITIES AND ORGANIZATIONAL SIZE?
}

Beatriz Forés, Universitat Jaume I, Department of Business Administration and Marketing Campus Riu Sec, Castellón, Spain, E-12071, corresponding author. Tel.: +34 964728551 ; fax: +34964728629

César Camisón, Universitat de València, Department of Business Administration Faculty of Economics, Avenida dels Tarongers s/n Valencia, Spain, E-46022, cesar.camison@uv.es

Acknowledgement: The authors gratefully acknowledge financial support from the National Plan for R\&D of Spanish Ministry of Economy and Competitiveness (ref. ECO2009-12522). 


\section{HIGHLIGHTS}

$>$ Incremental innovation performance is positively affected by internal knowledge creation capability and absorptive capability.

Absorptive capability affects radical innovation performance positively.

S Size has a direct positive effect on incremental innovation performance.

Size has a direct positive effect on internal knowledge creation capability. 


\title{
HOW DOES ORGANIZATIONAL SIZE IMPACT ON KNOWLEDGE ACCUMULATION CAPABILITIES AND INCREMENTAL VERSUS RADICAL INNOVATION PERFORMANCE?
}

\begin{abstract}
While prior studies recognise the importance of knowledge accumulation capabilities in innovation performance, current research has still failed to empirically identify its role with regard to different types of innovation performance. The objective of this paper is to address this knowledge gap and to explore the relationships between internal knowledge creation and absorptive capabilities, and radical and incremental innovation performance. The study also contributes to analyzing the complex effect that organizational size has in the whole innovation process, influencing its antecedents (internal knowledge creation capability and absorptive capability) as well as its outputs (incremental and radical innovation performance), as the literature has produced inconsistent results and the issue is subject to continuing debate. This study demonstrates that incremental innovation performance is positively affected by both knowledge accumulation capabilities and size. However, results show that only absorptive capability has a positive direct effect on radical innovation performance, whereas size has a negative non-significant effect on it. The effect of size on knowledge accumulation capabilities also turns out to be mixed. It appears to increase internal knowledge creation capability, but it does not affect the absorption of new external knowledge, and thus does not help to develop radical innovations.
\end{abstract}

Keywords: internal knowledge creation capability, absorptive capability, radical innovation performance, incremental innovation performance, size 


\section{INTRODUCTION}

The literature demonstrates that a firm's survival and generation of economic rents is explained by its ability to obtain both incremental and radical innovation performance, for which a balance between the two is required (March, 1991; He and Wong, 2004; Probst and Raisch, 2005; Farjoun, 2010). Although a high level of efficiency can be achieved with incremental innovation performance, radical innovation performance is needed to avoid generating competence traps (Levinthal and March. 1993). However, obtaining radical innovation performance is inherently more uncertain, involves higher levels of risk (Chandy and Tellis, 1998), and requires a long time period, and more intangible assets and tacit knowledge (Nonaka, 1994; Teece, 2007).

Innovation performance is studied in many disciplines and has been defined from different perspectives (Damanpour and Wischnevsky, 2006). This has led to a somewhat confusing definition of innovation performance in the literature, which mixes elements such as capabilities and attitudes with outcome elements. From the Competence-Based Approach, in the present paper the definition of innovation performance is limited to outcomes or consequences.

The dynamic aspects of the competence-based approach covered by the dynamic capabilities approach (e.g., Cepeda and Vera, 2007; Teece, 2007) shift the focus of analyzis to the study of the processes of knowledge accumulation to obtain innovation performance, as there seems to be some consensus in the literature that innovation is an outcome of new knowledge (Cohen and Levinthal, 1990; Kim et al., 2012; Tödtling et al., 2009). However, the literature identifying the key aspects to develop innovation performance based on knowledge accumulation capabilities (Jiménez-Jiménez and Sanz-Valle, 2011) requires additional conceptual and empirical research (Kim et al., 2012; van Wijk et al., 2008). Firms can accumulate new knowledge by generating it internally, through a process of internal 
knowledge creation grounded on the skills, knowledge and experiences of their employees (Smith et al., 2005), by acquiring it from external sources through the development of their absorptive capability (Cohen and Levinthal, 1990), or by implementing a strategy to accumulate new knowledge that combines both these options.

Prior studies in the literature focus on the antecedents of radical innovation performance (e.g., Herrmann et al., 2007). Numerous theoretical studies have analyzed the impacts that each of these knowledge accumulation capabilities has on innovation performance (e.g., Howells et al., 2003; Lichtenthaler and Lichtenthaler, 2009; Zahra and George, 2002). Recent empirical research analyzes the influence on innovation performance of different sources of knowledge, both internal and external to the firm (e.g., Cassiman and Veugelers, 2006; Vega Jurado et al., 2008). However, few empirical studies analyze the interrelationship between the different processes of knowledge accumulation in the firm and innovation performance from a perspective of capabilities (Jiménez-Jiménez and Sanz-Valle, 2011). Advances in the study of the impact and the relationships between a firm's different knowledge accumulation capabilities and its innovation performance have been truncated, mainly due to the lack of consensus and rigour in the conceptualisation and measurement of these capabilities, particularly absorptive capability (Camisón and Forés, 2010).

The lack of a direct empirical measurement for these knowledge accumulation capabilities has yielded divergent and sometimes contradictory results. If the literature analyzing the effect of knowledge accumulation capabilities on innovation performance is scarce and inconclusive, attempts to analyze the specific influence of each one of these knowledge capabilities, and their interrelationships, on different types of innovation performance according to their degree of radicalism are even more so. Most studies examining the effect of knowledge accumulation capabilities on innovation performance do so with regard to technological innovation (e.g., Darroch, 2005). Furthermore, almost all 
studies analyzing radical and incremental innovation performance focus on the effect that a specific knowledge source (internal or external) has on both innovative outputs, without adopting a capability-based approach that allows the conceptual distinction to be made between the different constructs (e.g., Cantner et al. 2011; Forsman, 2011; Ritala and Hurmelinna-Laukkanen, 2012; Soosay et al., 2008; Tödtling et al., 2009), thus hindering research from focusing on identifying the structures and processes through which they are developed.

Premised on the dynamic capabilities approach, this study attempts to analyze the extent to which different types of innovation performance rely on specific knowledge accumulation capabilities and the complex links among them. In other words, we attempt to study how different modes of knowledge accumulation can facilitate innovation performance with different levels of radicalness. This study also tries to clarify and extend the evidence on the effect of one of the most extensively analyzed organizational characteristics in the innovation field, namely organizational size (Camisón et al., 2004; Damanpour and Wischnevsky, 2006; Damanpour, 1992).

The literature demonstrates that the explanatory power of the organization members' capabilities and attitudes on innovation performance (e.g., Chandy and Tellis, 1998) is higher than that of certain organizational characteristics such as size. However, the effect of this variable on innovation performance is not altogether clear. While a number of studies have analyzed the direct effect of size on the degree of innovation (e.g., Arias-Aranda et al., 2001), and on innovation in terms of $\mathrm{R} \& \mathrm{D}$, new products and processes or patents (e.g., Cáceres et al., 2011; Laforet, 2008), less attention has been paid to controlling for this effect on different types of innovation performance. Moreover, the evidence of size on incremental and radical innovation performance reports contradictory results; although knowledge accumulation is one of the antecedents of innovation performance that, along with size, has been most widely 
studied, relatively little empirical research has been reported on the effect of size on internal knowledge creation capability and absorptive capability. The studies that assess the effect of size on knowledge management capabilities focus on knowledge transfer, also reporting inconclusive results (van Wijk et al., 2008). For this reason the present study aims to unravel the impact of organizational size on both radical and incremental innovation performance, and on the main knowledge accumulation capabilities that determine them, which will reveal in greater detail the complex antecedents and their interactions that intervene in the development of the innovation process.

The next two sections explain the theoretical framework and hypotheses. The methods and results are then reported. The final section discusses the main implications for theory and practice, the study limitations and future research avenues.

\section{THEORETICAL FRAMEWORK}

The dynamic capabilities approach emphasizes that to succeed, or even survive, firms must be able to continuously develop, improve and renew their products and processes, which protects them against imitation by their competitors and against the technological obsolescence resulting from the life cycle of the industry in which they are competing (Teece, 2007; Teece et al., 1997). Teece (2007: 1319) defines dynamic capabilities as those that "enable firms to create, deploy, and protect the intangible assets that support superior and long-run business performance".

The benefits and tangibility of dynamic capabilities depend on the underlying knowledge accumulation processes that allow firms to develop, gain, reshape and put into use new internal and external knowledge (Lichtenthaler, 2009). Analyzis of the knowledge accumulation process (Jiménez-Jiménez and Sanz-Valle, 2011) should pay attention to two sub-processes: internal knowledge creation and external knowledge absorption. The interplay between these two capabilities and innovation performance is the central point on which the 
exploratory model is built. The differentiation between the two knowledge accumulation capabilities is based on the nature of the sources of knowledge-internal or external to the firm—used to generate new knowledge (Denford, 2013; Zott, 2003).

Internal knowledge creation capability involves sustaining a continuous internal system for the creation, processing, dissemination and embodiment in the firm of new knowledge that increases the existing knowledge stock. According to Bierly and Chakrabarti (1996), internal knowledge creation occurs when members of the organization generate, transfer and integrate new knowledge within the boundaries of the firm. Internal knowledge creation capability entails the addition of new components in the firm's knowledge base through organizational creativity, experience, apprenticeship, experimentation, R\&D, and problem solving (Bontis et al., 2002; Nonaka, 1994; Smith et al., 2005). It also covers renewal of the knowledge stock through firm's employees exchanging their existing knowledge and combining it in new ways (Danneels, 2008; Helfat and Peteraf, 2003; Rosenkopf and Nekar, 2001; Zollo and Winter, 2002). As Smith et al. (2005) point out, implicit in the notion of exchange is the assumption that individuals hold different levels and types of knowledge and they will engage in teamwork and communication to learn from one another.

Internal knowledge creation is, fundamentally, generated by R\&D investment and internal problem solving (Grant, 2000). However, firms-particularly those belonging to lowand medium-technology industries—can create knowledge through other innovative activities that are not based exclusively on formal R\&D (Santamaría et al., 2009), mainly through creativity and experimentation. In the context of organizations as open systems, teamwork enables continuous internal knowledge creation by exploring complex and difficult issues from many points of view. It facilitates the sharing of strategies, ideas, and knowledge among members and across units and reduces misunderstandings, thereby enabling a common language, cognitive maps and a shared vision to develop (Nonaka, 1994). Teamwork is also 
considered a powerful tool to help integrate new knowledge within the organization that can subsequently be applied to different situations, guaranteeing the firm's constant strategic renewal. The firm's directors can also collaborate in the amplification and crystallisation of new created knowledge (Nonaka and von Krogh, 2009) by developing an appropriate structure, an organizational culture to attract and retain qualified human capital, a climate that favours risk taking, a leadership focused on knowledge creation and learning objectives, as well as a clearly recognisable mission to foster employees' identity and alignment with the firm's strategy (Nonaka, 1994; Smith et al., 2005).

Internal knowledge creation is usually a reaction to a perceived need for that knowledge which depends on the firm's experience and knowledge base (Smith et al., 2005). However, it should be recognised that as agents in constant contact with their external environment, members of a firm can create knowledge internally in the firm from external ideas or information. The contribution of both sources of knowledge to internal knowledge exploration is considered in the definition of the 'inventive capability' by Lichtenthaler and Lichtenthaler (2009). However, this internal knowledge creation derives from a latent internal need that is developed and managed within the organization. This internal stimulus does not require knowledge search processes that are formalised in cooperation agreements or in an established monitoring system within the firm. When the source of ideas is external, this study refers to the acquisition capability integrated in the construct of absorptive capability. This capability denotes the ability to transform external information into external knowledge prior to the accumulation of new knowledge; that is, before it is assimilated and integrated in the organization. Acquisition capability is grounded on formal processes for seeking, identifying, selecting and acquiring external knowledge, which are the processes that allow information to be transformed into knowledge, since the subjective component is also involved (Staples et al., 2001). In direct contrast to knowledge creation capability, where the firm is inward 
looking in its knowledge renewal and transfer efforts, is external knowledge absorptive capability, which involves using a mechanism to identify, acquire, assimilate, transform and apply knowledge not residing in the firm (Camisón and Forés, 2010; Zahra and George, 2002).

The absorptive capability construct is based on Zahra and George's (2002) fourdimensional model of absorptive capability. The absorptive capability construct here represents the most far-reaching reconceptualization. Zahra and George's (2002) reformulate Cohen and Levinthal's (1990) original three-dimensional model with four dimensions, including the transformation process. Table 1 describes the concept of each of these capabilities.

Acquisition capability integrates both the firm's capability to access external knowledge through contractual arrangements in the market and a permanent system of environmental monitoring. The inclusion of transformation capability calls for particular emphasis since, although neglected or implicitly included in the assimilation capability (e.g., Lane et al., 2006) in most of the literature on the absorptive capability construct, the firm's success in applying new external knowledge to its internal processes and operations to obtain radical innovation performance hangs on this capability (Zahra and George, 2002). Therefore, in contrast to Todorova and Durisin's (2007) proposal of transformation capability as an alternative to assimilation capability, and building on the conceptualisation of absorptive capability put forward by Zahra and George (2002) and Camisón and Forés (2010), this study posits that the acquisition of external knowledge, whether explicit or tacit, is destined to fail if the values, structures, systems and mental structures are not subsequently assimilated and transformed.

Despite the crucial role that the accumulation of new internal and/or external knowledge has to firms' survival, unless organizations convert new knowledge into new or improved 
products, processes or organizational methods (Cohen and Levinthal, 1990) matched with the context of their final market (Lichtenthaler and Lichtenthaler, 2009) superior rents will not be obtained (Bierly et al. 2009; Kogut and Zander, 1992). In this vein, although internal knowledge creation capability and absorptive capability comprise the conversion of new knowledge into reliable routines and capabilities (Wang and Ahmed, 2007), it is innovation performance that tests the reality and applicability of new capabilities generated in terms of new products and processes. Although authors such as Wang and Ahmed (2007) and Lichtenthaler and Lichtenthaler (2009) used the 'innovation capability' construct to capture the manifestation of internal and external knowledge accumulation capabilities, this study considers that a manifestation is better defined in terms of outputs or performance rather than capabilities.

As with the conceptualisation of innovation performance, the distinction between radical and incremental innovation performance is also complex and somewhat confused in the literature (Alexander et al., 2008; García and Calantone, 2002). Authors such as Koberg et al. (2003) associate product and service innovations with radical innovations, whereas they consider procedural, personnel, process and structural innovations to be incremental innovations. Conversely, Cantner et al. (2011), Forsman (2011), and Tödtling et al. (2009) consider innovation performance to be radical if it is a new product, service, process or method that differs dramatically from competitors in the firm's market. Atuahene-Gima (2005) and Darroch (2005) go even further in regarding new-to-the-world product innovations as radical.

This study distinguishes between incremental and radical innovation performance by considering the changes the firm obtains with respect to its previous technological and organizational path (Cooper and de Brentani, 1991; Damanpour, 1991). In this vein, this study considers radical innovation performance to be that which produces fundamental changes in 
the firm's products, processes, technologies and organizational structure and methods (Dewar and Dutton, 1986; Meyers and Tucker, 1989; Oslo Manual, 2005; Song and Montoya-Weiss, 1998), while incremental innovation performance entails the refinement and reinforcement of existing products, processes, technologies, organizational structure and methods (Chandy and Tellis, 1998; Oslo Manual, 2005). Table 1 provides a synthesis of the theoretical underpinnings of the constructs included in the study's conceptual model and their dimensions.

Table 1 here.

\section{RESEARCH HYPOTHESES}

\subsection{Internal knowledge creation capability and innovation performance}

Internal knowledge creation has irrefutable advantages for innovation performance. First, internal accumulation of knowledge provides greater control and coordination over the innovation process by reducing dependence on the external environment (Beneito, 2003). Second, internally generated knowledge is more easily assimilated and integrated into the firm's organizational patterns, culture and systems, in order to create new capabilities (Kessler et al., 2000; Todorova and Durisin, 2007). Third, tacit knowledge about techniques and products created through interaction among members of the organization has a high content of experiences and routines that are firm-specific, and not easily replicated or imitated by the market (Cantner et al., 2011; Nonaka, et al., 2000). Fourth, internal knowledge creation facilitates the absorption of new knowledge from the external environment (Cohen and Levinthal, 1990; Zahra and George, 2002).

Despite the advantages, the literature reports that internally generated knowledge has lower potential for introducing radical innovation performance (Rosenkopf and Nerkar, 2001), which limits its ability to create and/or sustain competitive advantages (e.g., Laursen 
and Salter, 2006; Lichtenthaler, 2009). Internally generated knowledge results from a previous knowledge base or stock in the firm, and is associated with incremental innovation performance that seeks to enhance existing organizational products, processes and methods, make operations more effective, improve quality and lower costs in a situation where the environment is fairly stable (Bierly and Chakrabarti, 1996; Dewar and Dutton 1986). Eisenhardt and Martin (2000) describe the risk of obsolescence when firms source all their knowledge internally. Internal knowledge creation capability thus biases an organization's problem-solving activities to focus on what has previously proved useful and on areas closely related to pre-existing knowledge or 'local search' (Teece, 2007). This "success trap"” receives support from recent empirical results suggesting that stablized firms tend to systematically overemphasise refinement and efficiency (Kim et al., 2012; Uotila et al., 2009).

Generating radically new knowledge within the firm, without the corresponding endeavour to identify, value, and acquire new market trends in products, processes, technologies and clients-in other words, the future evolution of the industry-is very likely to end in failure (Laursen and Salter, 2006). In addition, additional knowledge management research finds that very few firms have all the knowledge inputs required for continuous successful technological development (Bierly et al., 2009; Cassiman and Veugelers, 2006).

Zhou and Li (2010) argue that firms with a rich and diverse knowledge base, rather than acquiring new knowledge, need to combine it in different ways. However, the patterns that will dissipate if this new combination of existing knowledge fragments is successful in the market are determined precisely by the updated knowledge available about them when the puzzle is being assembled. In this vein, Laursen and Salter (2006) argue that although a diverse knowledge base may enhance the development of a variety of knowledge, without sufficient integration and implementation of new external knowledge through absorptive 
capability that knowledge will simply fail for radical innovation performance. Firms, therefore, need market knowledge about the application and commercialisation opportunities for their technological knowledge (Lichtenthaler, 2009).

Internal knowledge creation capability allows a company to improve the efficiency and reliability of incremental innovation performance (Hérnandez-Espallardo et al., 2012; Soosay et al., 2008). Nooteboom et al. (2007) supports this argument. Nooteboom et al. (2007) demonstrate the dual role of knowledge generated internally through $\mathrm{R} \& \mathrm{D}$. On one hand, this increases external knowledge absorptive capability (Cohen and Levinthal, 1990) (see hypothesis 4), while on the other hand it reduces the effect of cognitive distance on novelty value, making it increasingly difficult to find additional novel knowledge and, thus, radical innovation performance.

Therefore, the prior arguments inform the following hypothesis. H1: The greater the firm's internal knowledge creation capability, the higher its incremental innovation performance.

\subsection{Absorptive capability and innovation performance}

Chesbrough's (2006, p. 130) model of open innovation suggests that "a company that is too focused internally [...] is prone to miss a number of opportunities because many will fall outside the organization's current businesses or will need to be combined with external technologies to unlock their potential."

The use of knowledge from external sources expands a firm's knowledge base, enhances its recognition of opportunities and threats, eases the constraints from scarcity of internal resources-especially knowledge resources-, provides access to new ideas that promote the generation of new products and technology (Gupta et al., 2006; Lichtenthaler, 
2009) and enables the firm to improve and use existing knowledge and capabilities to transform its operations (Cohen and Levinthal, 1990).

Therefore, firms may invest in external learning to gain knowledge unrelated to their current areas of knowledge or to use knowledge that advances their existing technologies and products (Cohen and Levinthal, 1990; Ritala and Hurmelinna Laukkanen, 2012). The application of these two types of external learning in the firm has propelled innovation research, due to the important role that absorptive capability plays in obtaining incremental and radical innovation performance (e.g., Bierly et al., 2009; Lichtenthaler, 2009). Chiang and Hung (2010) argue that intensively accessing knowledge from a limited number of external channels can facilitate the innovating firm's incremental innovation performance, whereas accessing knowledge from a broad range of external channels can enhance the innovating firm's radical innovation performance. Similarly, studies such as that by Subramaniam and Youndt (2005) find that broader horizons with respect to knowledge sources are related to innovation success and radical innovation performance, respectively.

Hernandez-Espallardo et al. (2012) argue that bringing inter-organizational knowledge into the company not only increases its ability to obtain radical innovation performance, but also improves the likelihood that it will be commercially successful, as the business partners' commitment to the innovations increases. Soosay et al. (2008) analyze how firms engaged in different collaborative relationships can enhance both incremental innovation performance (such as enhanced processes, more efficient operations, better quality, and lower costs) and radical innovation performance (such as new technology implementation and a change in strategy) in the supply chain, based on ten case studies. In an empirical study of $443 \mathrm{New}$ Zealand firms, Darroch (2005) shows that knowledge acquisition and dissemination capabilities (both capabilities integrated in the study's conceptual delimitation of the 
absorptive capability construct) are related to both incremental and radical innovation performance.

The above insights support the following hypotheses. H2: The greater the firm's absorptive capability, the higher its incremental innovation performance. H3: The greater the firm's absorptive capability, the higher its radical innovation performance.

\subsection{Relationships among knowledge accumulation capabilities: Internal knowledge}

\section{creation and absorptive capability}

In particular, the logic of dynamic capabilities and 'open innovation' models suggests that absorptive capability is essential to obtain radical innovation performance in turbulent environments, where the rules of the market change rapidly and frequently make existing products obsolete (Chesbrough, 2006; Teece, 2007). However, it should be remembered that the generation and development of this capability in the firm depends on the internal development of qualified specialist technicians and scientists, and on a solid knowledge base (Cohen and Levinthal, 1990). The path-dependent nature of this absorptive capability, identified in the original studies by these authors, conditions part of their complementarity with the internal knowledge creation capability.

The ability to learn and develop knowledge internally requires cultural patterns and communication systems that open up the organization to change, thus facilitating its capability to absorb external knowledge (Cassiman and Veugelers, 2006). A broad and complex knowledge base facilitates the identification, acquisition, understanding and integration into internal operations of new external knowledge in key fields, and the detection of potential market and technological changes (Bierly et al., 2009; Zhou and Li, 2010).

The direct, positive relationship between internal knowledge creation capability and absorptive capability appears in the work of Purvis et al. (2001). Purvis et al. (2001) 
demonstrate that new knowledge about a methodology affects the absorption of this new methodology. In turn, Benson and Ziedonis (2009) show empirically that corporate venture capital (CVC) investment can improve the results obtained by corporate investors when acquiring start-ups if they have a strong internal knowledge base. Camisón and Forés (2011) also confirm the relationship between internal knowledge creation capability and absorptive capability, by demonstrating in an empirical study that even if firms are operating in environments where knowledge flows freely, such as industrial districts, the assimilation and application of these flows is heavily conditioned by the development of a previous internal knowledge base that enables them to be understood and integrated into the organization. Therefore, the above theoretical support informs the following hypothesis. H4: The greater the firm's internal knowledge creation capability, the higher its capability to absorb external knowledge.

The literature is in agreement about the complementarity of internal and external sources of knowledge with innovation performance. Howells et al. (2003) and Zack (1999) suggest that what is important to guarantee success in a firm's innovation process is the creative combination of different types of knowledge to obtain more knowledge than could ultimately be applied to obtain new products and processes. In a similar vein, Ellonen et al. (2009), based on qualitative data from the publishing industry, argue that companies that combine sensing, seizing and reconfiguration of dynamic capabilities (Teece, 2007) are better able to use existing technological and marketing capabilities to obtain and integrate new products and processes into their business and organizations. Tödtling et al. (2009) study of 400 Austrian firms shows that products new to a firm's market have a greater requirement for a combination of internal R\&D, and patenting and cooperation with universities and research organizations. Zhou and Wu's (2010) findings suggest that to sustain explorative or radical innovation performance in products, firms with strong technological capabilities must 
combine them with the development of dynamic capabilities that enable them to reallocate resources, to break down existing operational routines and to absorb and use new knowledge to address discontinuities in the environment.

As Li et al. (2008: 263) point out, "There is more tacit knowledge involved in radical innovation that in incremental innovation. To accomplish radical innovation, the partners involved [in an alliance] need [to] participate actively in the relevant organizational processes in which the tacit knowledge is embedded." Zhou and Li (2012) also note that without sufficient understanding and full integration and application of acquired knowledge, incremental improvement and refinement, but not the development of true breakthroughs, is more likely. Absorptive capability allows internal knowledge to be filtered and adapted to new market trends in new products, new processes, new designs and clients' tastes, and to the state-of-the-art in scientific and technological advances.

Combining sources of knowledge generates idiosyncratic knowledge that is more difficult for competitors to imitate, substitute and replicate than external knowledge available to the firm, and even more so than its own internal knowledge. Thus, the larger the knowledge base used to obtain an innovation and the more diverse the sources it comes from and the relationships between the different types of integrated knowledge, the more difficult it will be to imitate (Rivkin, 2001) and the more radical the innovation performance will be. Schoenmakers and Duysters (2010: 1057) conclude, "Firms that are quick in understanding the possibilities that emergent technologies possess, and that therefore are able to combine this knowledge with mature and well understood knowledge, might be better at delivering radical inventions”. In a similar vein, Knoppen et al. (2011) point out that increased innovation performance within a relational context implies the increasing importance of interorganizational learning-where the outcome of learning depends upon the interaction with partners-and the subsequent connection with intra-organizational learning. 
Therefore, firms increasingly compete on a deeper factor: the capability to combine and integrate their internal knowledge with knowledge from outside (Teece, 2007; Zahra and

George, 2002). Absorptive capability through its transformation component is, therefore, what facilitates the symbiosis between internal knowledge and external knowledge; in other words, it is what enables us to refer to the complementarity among knowledge sources to obtain radical innovation performance.

For this reason, the study here emphasises that internal knowledge creation capability should be developed simultaneously with absorptive capability in order to produce a valuable effect in the organization in terms of radical innovation performance (Kim et al., 2012). Therefore, H5: Internal knowledge creation capability has a positive indirect effect on radical innovation performance through the mediating effect of absorptive capability.

\subsection{Size and knowledge accumulation capabilities}

\subsubsection{Size and internal knowledge creation capability}

Larger versus smaller firms possess more financial and human resources (Arias-Aranda et al., 2001) with better formation and training (Cáceres et al., 2011). The availability of a broad, diverse team of people allows large firms to create new scientific and technological knowledge (Cáceres et al., 2011). On the other hand, in order to overcome the problems deriving from greater organizational complexity, large firms must create new organizational models that give them the flexibility and adaptability to deal with changes in the environment. Large size can therefore stimulate internal knowledge creation, because large firms are more predisposed to create this type of knowledge.

However, as firms become larger, they develop norms, values, and intra-organizational social networks for their operations (Tushman and O'Reilly, 1997) that become embedded in an organization and that reinforce the existing routines, mental models, procedures and 
structures. Moreover, the pressure of organizational inertia intensifies as a firm accumulates extensive technological and other organizational skills and forms its unique processes and routines (Zhou and Li, 2010). Thus, maintaining the status quo in larger organizations forces them to become more predisposed to maximise efficiency in employing their existing knowledge base and organizational structures (Vaccaro et al., 2012), entrenching the selfreinforcing nature of knowledge creation. Therefore, H6: The larger the company, the greater its internal knowledge creation capability.

\subsubsection{Size and absorptive capability}

Existing research demonstrates that as firms grow, they develop formal administrative systems and structures that slow their capabilities to recognise and adjust to shifting environmental conditions (e.g., Cohen and Levinthal, 1990; Haveman, 1992; Leiblein and Madsen, 2009), and make them more susceptible to competence traps (Levinthal and March, 1993; Sorensen and Stuart, 2000) than small firms.

The assimilation and integration of external knowledge through knowledge transfer among the firm's different units are sometimes key factors driving the development of absorptive capability. Large organization size is typically attended by greater structural complexity, such as a large number of hierarchical levels (Blau and Schoenherr, 1971). This hierarchy raises the costs of coordination among the firm's units and, therefore, its capability to combine knowledge, particularly knowledge with a high tacit component (Leiblein and Madsen, 2009). Small firms possess the entrepreneurial culture needed to grasp the market opportunities that lie outside the firm's boundaries (Rothwell, 1983).

In addition, as well as being able to apply informal and strategic controls more easily, smaller firms are better able to select and lure top talent than large firms due to their comparative advantage in utilising performance contingent contracts and other incentive 
systems (Leiblein and Madsen, 2009). Smaller firms applying knowledge acquired from the external environment to innovation performance is easy because their structures are less complex, their internal and external communication flows more freely, and they can more easily identify the various dissemination and, finally, application elements of the new knowledge. Therefore, H7: The larger the company, the lower its absorptive capability.

\subsection{Size and innovation performance}

Authors building on Schumpeter's classic arguments suggest that large firms have many advantages over small ones in their capability to obtain radical innovation performance. They point out that large firms enjoy economies of scale in research and development, can spread risks widely, and have greater access to market and financial resources. In this vein, authors such as Forsman and Annala (2011) and Levinthal and March (1993) state that incremental innovation performance is more common in small firms. Dewar and Dutton (1986) and Germain (1996) find that although size has a positive effect on radical process innovation performance, this effect is non-significant on incremental process innovation performance.

Although large firms have sufficient resources for investing in innovation, they suffer from a variety of issues that may make them less innovative. Some researchers argue that as firms grow, they become more bureaucratic, slower to react, and less willing to take risks and encourage creativity (Damanpour and Wischnevsky, 2006). Nooteboom et al. (2007) add that large size may yield larger coordination costs, less autonomy, less flexibility, and a greater probability of original ideas being rejected in a multi-level hierarchy of evaluation. Laforet (2013) points out those small and medium-sized firms (SMEs) are more cost-effective in innovation and have quicker response times when implementing new technologies and meeting specific customer needs than larger firms because of their better management control. Dougherty and Hardy (1996) go as far as stating that size correlates negatively with the adoption of radical innovation performance because of difficulty in connecting the necessary 
capabilities, resources and strategies that must accompany the process. As a result large firms are less likely to produce radical innovation performance. For their part, Ettlie et al. (1984) show a non-significant effect of size on radical technological innovation performance (comprising product and process innovations) and a positive effect on incremental technological innovation performance.

Ettlie and Rubenstein (1987) report the relationship between radical innovation performance and size is bell-shaped (). Conversely, Pavitt (1990) and Tsai and Wang (2005) find a U-shaped curve, suggesting that medium-size firms have the liabilities of large and small firms and few of their strengths.

Therefore, the literature includes conflict about the impact of size on innovation performance. Larger firms are likely to have greater resources and capabilities that allow them to extend their existing knowledge base. That is, larger firms devote more effort to accumulating knowledge that perpetuates the innovation performance arising from their consolidated research lines. This path dependence in large corporations creates bureaucratic and cultural sources of structural inertia that can inhibit the entrepreneurial spirit of their employees to introduce radical innovation performance. In light of the above insights, the following hypotheses were put forward. H8: The larger the company, the greater its incremental innovation performance. H9: The larger the company, the lower its radical innovation performance.

\section{RESEARCH METHOD}

\subsection{Sample}

The data were collected from Spanish industrial firms (with the exception of the energy sector) registered in Spain's National Statistics Institute Central Company Directory. The average size of firms in the energy sector is much greater than in the rest of Spanish industrial 
firms; hence, firms from this sector were excluded to avoid statistical problems due to the existence of outliers. The initial sample size was set at 2,000 firms to guarantee a maximum margin of error of \pm 2.2 with a confidence interval of $95.5 \%$. A stratified random sampling was used on the basis of industry and firm size. The population was classified into 14 sectors according to 3-digit SIC codes, and into four size groups following the European Union's definition of micro, small, medium and large firms (the number of employees $<10,10-49,50$ 249 , and $\geq 250$, respectively). An optimal sample allocation procedure was used in each group, and simple random sampling to select cases until the allocated size was reached.

The information was gathered through self-administered electronic questionnaires, using a web-page-based instrument for data collection (Stanton and Rogelberg, 2001), between February and May 2007. The questionnaire was sent by e-mail to the sample firms' President, Chairperson, or CEO, taking necessary measures to ensure the anonymity and security of the respondents (one respondent for each company) (Simsek and Veiga, 2001). The questionnaire was sent twice, and was followed up with a phone call to nonrespondents. A total of 952 firms returned usable responses, providing a response rate of $47.6 \%$.

The possible existence of non-response bias was explored with a time trend extrapolation test (Armstrong and Overton, 1977). This test operates under the assumption that 'early' and 'late' respondents are not significantly different. No significant differences in explanatory or dependent variables were detected from the $t$ tests $(p>.05)$, suggesting an absence of non-response bias in terms of firm characteristics.

To test the validity of both the research findings and the measurement instruments included in the questionnaire, a methodological triangulation exercise was performed by combining different methods (Creswell, 2003). The triangulation method enhances the credibility of results while reducing the risk of observations that reflect some artefact or bias inherent in any single method (Denzin, 1978). Elements from qualitative study and 
quantitative survey methods were combined. Qualitative inquiry prior to the distribution of surveys (Jick, 1979) was administrated through a pre-test of the questionnaire in 14 firms

randomly selected from the sample for the survey research. The purpose of the pre-test was to ensure that the statements were understood without ambiguity and to collect suggestions about their design (Podsakoff et al., 2003). Following the quantitative survey, a second qualitative inquiry was undertaken through a personal interview with 36 chairpersons or CEOs, in which the answers initially included in the questionnaire were tested. We also supported the responses through direct observation and an analyzis of the firms' internal documents. These inquiries demonstrate the validity of the responses to the quantitative survey, and show that the questionnaires were answered.

\subsection{Analytical techniques}

A structural equations model (SEM) was used with two stages to test the theoretical model (Anderson and Gerbing, 1982; Hair et al., 1998). The EQS 6.1 software package was used to estimate structural models, and the maximum likelihood method with robust estimators to estimate the parameters to alleviate the requirements of normality (Satorra and Bentler, 1994).

\subsection{Measurement of variables}

Figure 1 shows the study's operational model including the constructs and their items. Descriptions of each item are given in the Appendix. If all questions for the same dimension of a construct are presented in related sections, responses might not be independent; to prevent this we randomised the presentation of questions in the questionnaire by mixing the items (Podsakoff et al., 2003). In order to avoid the "robot effect" in responses and diminish the risk of biases, a control process consisted of formulating certain items inversely (see Appendix) was selected. 
Figure 1 here.

Managerial self-evaluations have precedence in measuring firms' resources and capabilities and have been found to be convergent measurements with equivalent objective indicators (e.g., Camisón and Forés, 2010). However, common method variance is a problem that can arise when the dependent and independent variables are collected from a single respondent. In order to reduce this potential problem, dependent variables were placed after independent variables in the questionnaire to reduce the impact of nonrespondents' implicit effectiveness theories (Podsakoff and Organ, 1986). Since all three constructs were measured using items in a questionnaire completed by a single respondent, we also examined whether common method variance was a serious issue by conducting Harman's one-factor test (Podsakoff and Organ, 1986). In this test, all items are entered together in a factor analyzis, and the results of the unrotated factor solution are examined. If substantial common method variance is present, either a single factor would emerge, or one general factor would account for most of the covariance in the independent and criterion variables (Podsakoff et al., 2003; Podsakoff and Organ, 1986). All items, 6 measuring internal knowledge creation capability, 14 measuring absorptive capability, 4 measuring radical innovation performance and 3 measuring incremental innovation performance, were used in a principal components factor analyzis. No general factor was apparent in the unrotated factor solution. Moreover, this study verified the convergent validity of the subjective measures from self-evaluation with objective measures both internal and exogenous to the firm (Podsakoff et al., 2003) (details below). The statistical tests do not eliminate the threat; however they suggest that the results are not driven predominantly by common method variance.

\section{Internal knowledge creation capability}

In spite of the extensive literature on internal knowledge creation capability, the lack of consensus surrounding this construct has given rise to an insufficient debate about its 
measurement (Easterby-Smith et al., 2000). The majority of these studies measure internal knowledge creation capability through R\&D spending (e.g., Bierly and Chakrabarti, 1996). The excessive focus on the analyzis of R\&D makes it impossible to move forward in the study of this capability for the internal development of knowledge in firms where these activities are less evident (as in the case of SMEs) or less intensive (as in low-tech industrial sectors). Following the theoretical definition given above in this paper, internal knowledge creation capability was defined as a unidimensional multi-item scale, following the line proposed by García-Morales et al. (2007). The six items comprising the scale are the result of a thorough review of the literature (e.g., Goh and Richards, 1997; Templeton et al., 2002), in which additional efforts were made to select aspects related to the learning and creation of knowledge, and the discovery of new solutions within the firm. Specifically, these attributes gather managers' and employees' commitment to change and learning, firms' abilities to develop an innovation culture, an organizational design open to learning, and investment in R\&D (Appendix, Section 1).

\section{Absorptive capability}

Several theoretical studies recognise the importance of absorptive capability as a multidimensional capability (e.g., Camisón and Forés, 2010; Flatten et al., 2011; JiménezBarrionuevo et al., 2011; Zahra and George, 2002; Volberda et al., 2010). However, although absorptive capability has received wide recognition, in prior empirical studies it has mainly been applied as a one-dimensional construct (Lim, 2009); that is, "either external knowledge is understood, transferred, and applied, or it is not" (Bierly et al., 2009, p. 482). Rothaermel and Alexandre (2009) analyze the impact of different knowledge sources on innovation adopt a concept of absorptive capability that either does not allow it to be differentiated from internal knowledge creation capability by using proxies or R\&D related variables (e.g.,) and variables relating to the skills and motivation of employees to create internal knowledge (e.g., 
Liao et al., 2007), or neglects the firm's internal efforts in acquiring knowledge by linking the construct exclusively to external knowledge acquisition through contractual arrangements in the market, particularly the purchase of licences (e.g., Cassiman and Veugelers, 2006), R\&D contracts (e.g., Cassiman and Veugelers, 2006), hiring of personnel (e.g., Cassiman and Veugelers, 2006), acquisitions of other firms (e.g., Cassiman and Veugelers, 2006) or other forms of cooperation (alliances or collaborations) related particularly to R\&D (Bierly and Chakrabarti, 1996; Ritala and Hurmelinna-Laukkanen, 2012). These studies, therefore, move away from the original conception of the construct (Cohen and Levinthal, 1990), thus losing its meaning as a dynamic capability (Zahra and George, 2002). Based on the four dimensions of the absorptive capability identified by Zahra and George (2002) and Camisón and Forés (2010), the construct was measured taking 19 items from the Camisón and Forés (2010) scale, presented in Section 2 of the Appendix.

\section{Incremental innovation performance}

Some items from Atuahene-Gima (2005), Li, Liu, Li and Wu (2008) and Ritala and Hurmelinna-Laukkanen (2012) were used to measure firms' refinement, improvement, and adaption of existing products, processes, technologies and organizational structures, strategic orientations, techniques and management methods (Forsman, 2011; Oslo Manual, 2005) (Appendix, Section 3).

\section{Radical innovation performance}

Some items were used from Atuahene-Gima (2005), Chandy and Tellis (1998), Li, Liu, Li and Wu (2008), and Ritala and Hurmelinna-Laukkanen (2012) which reflect the firm's introduction of radical new products (covering both goods and services), processes, technologies and organizational structures, strategic orientations, techniques and methods 
departing from existing ones (Cooper and de Brentani, 1991; Dewar and Dutton, 1986; Forsman, 2011; Oslo Manual, 2005) (Appendix, Section 4).

Size

Size was measured by a continuous scale using the number of employees in the firm, which is the most commonly applied proxy for size in previous studies related to innovation performance (e.g., Camisón et al., 2004; Tsai and Wang, 2005; Zhou and Wu, 2010).

\section{Control variables}

The study controls for both firm-specific characteristics (age and number of hierarchical levels) and external (general environmental uncertainty and competitive environment attractiveness) factors that might either influence the innovation performance of a firm directly, or may lead to an over- or underestimation of the relationships of the conceptual model.

Age was measured by the number of years since a firm was founded and computed by the difference between the year 2006, the year the data is based on, and the year the firm first entered the industry.

Number of hierarchical levels is a reflection of a firm's organizational structure and was measured by a continuous scale using the number of hierarchical levels between the general management and the line workers.

General environmental uncertainty reflects the dynamism, complexity and hostility of the environment shared by all companies in the nation. General environmental uncertainty was operationalised using a 25-item scale developed by Dess and Beard (1984). Respondents evaluated each item on a five-point Likert scale, in which 1 describes the most stable and certain environment and 5 the most uncertain environment. Environmental uncertainty was measured by taking the average rating of the items. 
Competitive environment attractiveness captures the influence derived from the structural features of each sector that determine the competition within it, and the positions of competitors. Competitive environment attractiveness was measured by a 30 -item scale based on the five competitive forces model developed by Porter (1985): bargaining power of customers and suppliers, threat of substitutes and new competitors, and competitive rivalry. Respondents evaluated each item on a five-point Likert scale, in which 1 described the most turbulent environment and 5 the most attractive environment. Competitive environment attractiveness was measured by taking the average rating of the items. Table 2 provides descriptive statistics and correlations for all variables.

Table 2 here.

\section{RESULTS}

\subsection{Measurement model}

To develop a measurement model, a joint confirmatory factor analyzis was run for all latent factors (Table 3 ). This analyzis resulted in certain modifications to the initial model in order to achieve a good fit; namely, items AC4, AS4, AS5, TR3 and AP2 from the initial absorptive capability scale and item II4 from the initial incremental innovation performance scale were eliminated following the instructions of the LMTEST. The study examined the goodness of fit of the factor models on the basis of the estimation technique proposed by Hair et al. (1998), which showed the dimensionality of the constructs proposed $(\mathrm{NNFI}=0.984, \mathrm{CFI}=0.986, \mathrm{IFI}$ $=0.986, \mathrm{RMSEA}=0.021, \mathrm{NC}=1.132$, Table 3$).$ The study included a regression analyzis to demonstrate the consistency of the results obtained through an alternative statistical technique. The findings support the original model specification, highlighting the importance of the interaction effect between absorptive capability and internal knowledge creation capability to radical innovation performance. 
Table 3 here.

To estimate the reliability of the latent constructs, the composite reliability index was calculated — which was greater than 0.60 , the minimum value recommended by Churchill (1979) for exploratory studies — for all the factors (Table 3). The $\mathrm{R}^{2}$ statistic (Hair et al., 1998) was used to estimate the reliability of the individual items. The standardised loadings were higher than the minimum value of 0.5 (Hair et al., 1998) for all except two items (TR5 = $0.427, \mathrm{RI} 2=0.487$, Appendix). Since these values were close to the minimum level, the items were kept in the scale so as not to weaken the definition of the respective construct domains. Also, in all cases the factor loadings were positive, statistically significant in the factor to which they were assigned, and zero in other factors.

Discriminant validity of the correlations matrix between each of the model's dimensions (Table 2) was evaluated. The correlations between the dimensions of the same construct were greater than the correlations with the dimensions of other constructs, and the correlation between different constructs and their respective dimensions was less than 0.6 (Churchill, 1979), confirming the discriminant validity of the model. A complementary assessment of discriminant validity was performed with Chi-square difference tests on the values obtained for the unconstrained model (i.e., a model where the factor correlations are not constrained to unity) and the constrained model (Anderson and Gerbing, 1988) for absorptive capability. A significantly lower Chi-square value was obtained from the unconstrained model than from the constrained model, which indicates that the factors are not perfectly correlated (Table 4). The non-significant differences between the pairs of dimensions of absorptive capability indicate that while these constructs do measure something in common, each dimension measures something unique on its own.

Table 4 here. 
The convergent validity was tested in three ways by: (1) the fit of the model; (2) the standardised factor loadings (minimum of 0.50); and (3) the significance of factor loadings (Anderson and Gerbing, 1982). The last test showed that all loadings were statistically significant $(\mathrm{t} \geq 1.96 ; \alpha=0.05)$.

Finally, both concurrent and predictive criterion validities were evaluated. The concurrent validity was tested by verifying whether the measurement of capabilities on the basis of managers' perceptions is convergent with the objective measurement on the basis of quantitative data. The comparison was made for four items: (1) AP3, correlated with the number of patents; (2) TR1, correlated with the number of information technology-based innovations introduced by the firm; (3) AC2, correlated with the number of technological cooperation agreements established by the firm; and (4) AS5, correlated with the percentage of firm personnel involved in external knowledge-based activities. The Pearson's correlation coefficients were positive $(0.45,0.34,0.37$, and 0.30 , respectively) and statistically significant $(\mathrm{p}<0.01)$. The predictive validity, following the Resource-Based View that identifies capabilities as basic sources of economic rents, was tested by the correlation between the absorptive capability scale and organizational performance. Performance was measured by ROA from the 2007 annual accounts compiled in the Iberian Balance Sheet Analyzis System (SABI) database. The results indicated positive correlations $(\mathrm{p}<0.001)$ between ROA and both PACAP $(r=0.55)$ and RACAP $(r=0.49)$.

\subsection{Structural model}

The hypotheses were jointly assessed by the structural model (Figure 1). The model is over-identified (degrees of freedom $>0)$ and has adequate fit indexes $(\mathrm{NNFI}=0.997, \mathrm{CFI}=$ $0.998, \mathrm{IFI}=0.998, \mathrm{MFI}=0.988, \mathrm{NC}=1.017, \mathrm{RMSEA}=0.007)$. All the parameters were significant at the 0.05 level, the factor loadings were greater than 0.50 for all except one item $($ TR5 $=0.451$, Figure 1$)$, and the composite reliabilities exceeded 0.60. The hypothesised 
model explained $23 \%$ of the variance in firm's incremental innovation performance $\left(\mathrm{R}^{2}=\right.$ $0.234)$ and $65 \%$ of the variance in firm's radical innovation performance $\left(\mathrm{R}^{2}=0.652\right)$.

Firm age does not significantly affect incremental $(0.058$, n.s. $)$ and radical $(0.063$, n.s. $)$ innovation performance. The finding on age may reflect the inconclusiveness of its relationship with innovation, as scholars' research results vary (Cohen and Levinthal, 1990; Damanpour and Wischnevsky, 2006; Sorensen and Stuart, 2000). The number of hierarchical levels had a positive effect on incremental innovation performance, albeit with a relatively low path coefficient $(0.074, \mathrm{p}<0.05$,$) and a negative non-significant effect on radical$ innovation performance $(-0.040$, n.s.). These results confirm the thesis of authors such as Arias-Aranda et al. (2001) and Jones and Butler (1992) highlighting that the hierarchies established in larger firms contribute to conservatism and to obstructing incentives for individual scientists and entrepreneurs. Formal procedures and structures provide each individual agent with less opportunity to demonstrate his or her discrete innovative contributions. Managers in larger organizations develop bureaucratic procedures to reduce risks, maintain stability and improve efficiency when the hierarchy and rules replace ad hoc methods of operation (Jones and Butler, 1992) and undermine new resource allocation patterns (Gilbert, 2005). These mechanical structures favour the improvement of existing products, processes and methods, that is, incremental innovation performance, but can generate strong pressure against radical changes from the status quo, which provide uncertain returns (Zhou and $\mathrm{Wu}, 2010)$. The inclusion of the internal control variable 'number of hierarchical levels' allows us to test the robustness of the results of the effect of size on both types of innovation performance, as the literature has considered it a good indicator of firm's size (Baldridge and Burnham, 1975; Jones and Butler, 1992).

The control variable referring to attractiveness of the competitive environment significantly affects both incremental $(0.118, \mathrm{p}<0.05)$ and radical innovation performance 
$(0.107, p<0.05)$, confirming the basic paradigm of the industrial organization field. However, the finding of uncertainty concerning the general environment differs according to innovation type. The effect on incremental innovation performance is negative and significant $(-0.084$, $\mathrm{p}<0.05$ ), confirming the contingent proposition from organization theory. However, the empirical results show that the general environmental uncertainty did not significantly affect radical innovation performance $(0.033, \mathrm{n} . \mathrm{s}$.). The results therefore suggest that a competitive environment of the most attractive industry, namely, the industry with the greatest potential to generate rents, will probably allow a greater accumulation of financial resources for the firm to invest in both incremental and radical innovation performance, the latter demanding a higher budget. In contrast, a generally uncertain and unattractive environment increases the risk of innovation performance and is therefore a disincentive to embark on changes, even incremental changes. The non-significance of the effect of general environment uncertainty on radical innovation performance is more difficult to explain, however. Radical innovation performance might be not incentivised in turbulent environments, although this can occur because a change in the business model can reshape the environment itself.

H1, predicting that internal knowledge creation capability has a positive relationship with incremental innovation performance, receives support $(\beta 1=0.203, p<0.01$, Figure 1$)$. Regarding the effects of absorptive capability on innovation performance, $\mathrm{H} 2$ and $\mathrm{H} 3$, predicting a positive association between absorptive capability and incremental and radical innovation performance, respectively, were also supported $(\beta 2=0.244, p<0.01 ; \beta 3=0.804$, $\mathrm{p}<0.001$; Figure 1). H4 suggests that firms with a greater capability for internal knowledge creation would have a higher capability to absorb external knowledge. The structural model confirms this hypothesis, indicating a direct, positive and statistically significant relationship between the two constructs $(\beta 4=0.565, \mathrm{p}<0.001$, Figure 1$)$. H5, predicting that internal knowledge creation capability has a positive relationship on radical innovation performance 
through absorptive capability, receives support $(\beta 5=0.454, \mathrm{p}<0.001$, Figure 1$)$. The results show that absorptive capability acts as a fully mediating variable on the development of new products, processes, technologies and management methods. H6 suggested that larger firms would have a greater capability to create knowledge internally. The results confirm this hypothesis, as they indicate a direct, positive and statistically significant relationship between the two variables $(\beta 6=0.169, \mathrm{p}<0.01$, Figure 1$) . \mathrm{H}$, predicting that larger companies have correspondingly lower absorptive capability, cannot be confirmed, as the results show that the relationship between the constructs does not receive support $(\beta 7=0.059$, n.s., Figure 1$)$. H8 suggests that the firms' capability to obtain incremental innovation performance would be greater, the larger the firm. The structural model confirms the existence of a direct, positive and statistically significant relationship between the two constructs $(\beta 8=0.156, p<0.001$, Figure 1). However, H9, predicting that the larger the company, the lower its radical innovation performance, does not receive support $(\beta 9=-0.070$, n.s., Figure 1$)$.

\subsection{Alternative model evaluation}

The hypotheses in the model (Figure 1) establish a fully mediating effect of absorptive capacity on the relationship between internal knowledge creation capability and radical innovation performance. Following the recommendations for the evaluation of causal models in management research (Baron and Kenny, 1986; Piccolo and Colquitt, 2006), and considering the complexity of the study's final model, additional analyzes were conducted to test the validity of a non-mediated model (Model 1, Figure 2), a partially mediated model (Model 2, Figure 3), and a fully mediated model (Model 3, Figure 4), focusing on the analyzis of the relationships between internal knowledge creation capability, absorptive capability and radical innovation performance.

The fit of these alternative models were tested by the significance of change in chisquare (Kline, 1998). All three models fit the data well: Model $1(\mathrm{NNFI}=0.936 ; \mathrm{CFI}=0.937$, 
$\mathrm{IFI}=0.937, \mathrm{NC}=1.689, \mathrm{RMSEA}=0.042), \operatorname{Model} 2(\mathrm{NNFI}=0.978 ; \mathrm{CFI}=0.981, \mathrm{IFI}=$ 0.981, $\mathrm{NC}=1.205, \mathrm{RMSEA}=0.023)$, and $\operatorname{Model} 3(\mathrm{NNFI}=0.998 ; \mathrm{CFI}=0.999, \mathrm{IFI}=0.999$ $\mathrm{NC}=1.014, \mathrm{RMSEA}=0.006)($ Figures 2,3 and 4$)$.

However, the chi-squares in Model 1 and Model 2 are significantly greater than that in Model 3, which represents the fully mediating relationship among the variables included in the hypothesised model $\left(\Delta \chi^{2}=159.80, \mathrm{p}<.001 ; \Delta \chi^{2}=43.93, \mathrm{p}<.001\right)$, confirming that the hypothesised model represented a better fit than the alternative models (Kline, 1998).

A regression analyzis was performed to test the consistency of the results obtained through an alternative statistical technique. Results supported the study's original model specification, highlighting that the influence of internal knowledge creation capability on radical innovation performance is achieved through absorptive capability. Furthermore, a comparison of the two alternative models reveals that the partially mediated model (Model 2) obtains a much better fit than the non-mediated model (Model 1), reinforcing the complementarity between internal and external knowledge accumulation capabilities to radical innovation performance.

Figures 2, 3 and 4 here.

In addition to these tests, a comparative analyzis was performed for the whole structural model. Unfortunately findings on the direct effect of internal knowledge creation and absorptive capability on radical innovation performance cannot be reported due to problems in running the model with EQS, derived from the miss-adjustment of this direct effect model. The comparison of the results of the hypothesised fully mediated model (Figure 1) with those of a partially mediated model (Figure 5) reveals that although this alternative model fits the data well $(\mathrm{NNFI}=0.995 ; \mathrm{CFI}=0.995, \mathrm{IFI}=0.995, \mathrm{NC}=1.035, \mathrm{RMSEA}=$ $0.011)$, the chi-square is significantly greater than that in the hypothesised model $\left(\Delta \chi^{2}=7.25\right.$, $\mathrm{p}<.01$ ), and this partially mediated model is also less parsimonious, as it includes the non- 
significant relationship between internal knowledge creation and radical innovation performance.

Figure 5 here.

\section{DISCUSSION}

Building on the dynamic capabilities perspective, this study examines the effects of internal knowledge creation capability, absorptive capability and size on incremental and radical innovation performance. The study here includes the findings that both internal knowledge creation capability and absorptive capability have a positive effect on incremental innovation performance. However, only firms that combine their internal knowledge base with knowledge from external sources can obtain a positive impact on radical innovation performance. The study also confirms that large incumbents within the industry favour exploiting existing technologies through incremental innovation performance (Koberg et al., 2003).

The findings contribute to the existing literature in several ways. First, this study helps to unpack the 'black-box' of organizational capabilities by delimitating the conceptual and empirical frontiers between two organizational learning processes that, although interrelated, are grounded on different components. The findings provide support for the view that as firms develop their internal knowledge creation capability, they are better able to apply the new knowledge created to refine and extend product, process and management methods, that is, to generate incremental innovation performance, but not radical innovation performance. This finding is in accordance with prior studies (e.g., Bierly and Chakrabarti, 1996; Lavie, 2006) which suggest that internal knowledge creation capability generates new knowledge for the firm that maximises the potential of current knowledge base and capabilities, and strengthens the firm's established positions. Incremental innovation performance can allow firms to 
sustain their competitive advantages in the short term and in conditions of environmental stability. Bridging the temporal and economic gap that the firm needs to obtain radical innovation performance is necessary. However, to create and maintain competitive advantage in current competitive arenas firms should create new products, processes and management methods. Firms pursuing the development of radical products, processes, technologies and management methods should invest in developing their capabilities to absorb new external knowledge (Lavie, 2006). As pointed out earlier, this study emphasises the multi-dimensional nature of this complex construct, and explicitly recognises the importance of transformation capability to combine new external knowledge with the existing knowledge base and mental models in order to create a more tacit and specific knowledge that is not observable easily and thus imitated by competitors (Lichtenthaler, 2009). The study by Kogut and Zander (1992) supports the importance of external knowledge to reactivate internal knowledge. Cassiman and Veugelers (2006) and Tödtling et al. (2009) find evidence that more versus less advanced and superior innovation performance, respectively, have greater requirements for a combination of internal and external sources of knowledge.

Nevertheless, the present study confirms that the creation of a diverse and rich internal knowledge base through internal knowledge creation capability is critical for the development of absorptive capability, which supports Cohen and Levinthal's (1990) assertion that absorptive capability is path-dependent in nature. This may also explain why firms exposed to the same amount of external knowledge flows might not derive equal innovation performance (Camisón and Forés, 2011; Escribano et al., 2009). In addition to external knowledge absorption, firms need to develop their internal knowledge creation capability in order to rapidly (Schoenmakers and Duysters, 2010) distribute, combine and apply current and newly acquired external knowledge to develop radical innovation performance. In this vein, the results of the empirical analyzis demonstrate that firms which also develop and combine their 
internal and external knowledge accumulation capabilities obtain greater radical innovation performance, according to the comparison of fits and psychometric properties uncovered by the theoretical models tested. These results thus contradict research which posits that high levels of one knowledge accumulation process (e.g., internal knowledge creation capability) would imply low levels of the other process (e.g., absorptive capability) as firms compete for scarce resources (Gupta et al., 2006; Vega-Jurado et al., 2008).

Although organizational size is not the main antecedent of business innovation performance, size is an important antecedent factor to take into account (Camisón et al., 2004; Chandy and Tellis, 1998). Analyzis of organizational size in this study on the development of knowledge accumulation capabilities and innovation performance has yielded some revealing results. Specifically, they confirm that although organizational size positively affects internal knowledge creation capability, size has no impact on absorptive capability. Furthermore, the results show that larger firms enjoy greater advantages for incremental innovation performance (Koberg et al., 2003) but not for radical innovation performance on which large firm size has a negative non-significant effect (Abernathy and Utterback, 1978). These results corroborate those by Ettlie et al. (1984). Large firms rarely introduce radical innovation performance; rather they tend to solidify their market positions with relatively incremental innovations (Chandy and Tellis, 2000).-Large firms with strong knowledge bases may become so entrenched in existing technology trajectories that they might overlook emerging knowledge and technologies from new territories (Levinthal and March, 1993; Nooteboom et al., 2007). Large firms also discourage radical departures from the status quo, which would require a different set of rules and processes. The results thus support O'Reilly and Tushman's caution to managers that "being large and successful at one point in time is no guarantee of continued survival" (2008:186). Therefore, firms with a large number of employees should invest resources in developing practices that promote communication and 
coordination between different parts of the organization and between the organization and the agents in the environment, and that establish more organic and flexible hierarchical structures (Tsai and Wang, 2005; Zhou and $\mathrm{Wu}, 2010$ ). The distinction between different types of innovation performance in this study can help to solve the inconclusiveness of the relationships between size and innovation performance, as positive, negative, and curvilinear relationships have been put forward in the literature (Sorensen and Stuart, 2000).

This study has a number of limitations that might also constitute opportunities for future research. First, the responses are based on self-evaluation by a single respondent, in this case the firms' managers, which may cause problems of internal validity, although we have tried to minimise the risk of bias. Second, the sample includes firms from different industries; however, it is limited to Spanish firms only. While no specific reason supports the believe that nationality might bias the results in a predictable direction, the findings may be peculiar to Spanish firms and should be interpreted with caution until they are confirmed in other nations with different economic systems and organizational structures. It would also be interesting to assess whether these results are generalizable to service industries.

Third, although the results confirmed the hypotheses, the study is to some degree exploratory as two new scales were developed for inherently difficult to measure organizational processes. Further testing and possible enhancement of these measurement scales is advised. Future studies may also try to operationalise these constructs using objective measures and examine their associations with the study's perceptual measures.

Fourth, the data used in this study are cross-sectional, which allow us to analyze only one specific organizational condition at a time, not organizational conduct over time. Although measurement scales with items that reflect dynamic characteristics were used, longitudinal data are needed to truly examine the dynamics of organizational capabilities. Interpret the study's findings as an association between variables and not in terms of 
causality. Future studies should adopt a longitudinal approach to analyze the possible recursive relationships between internal knowledge creation capability, absorptive capability and both types of innovation performance, to tackle how to achieve a balance between them, as the literature is inconclusive. For example, Benner and Tushman (2003) propose the simultaneous development of capabilities that favour both radical (explorative) and incremental (exploitative) innovation performance, whereas authors such as Burgelman (2002) suggest that the development of capabilities and innovation performance should be cyclical, encouraging radical innovation performance first, followed by periods of incremental innovation performance.

Fifth, future research may include in the theoretical model the impact of contingent factors such as organizational structure and strategy design (Van den Bosch et al., 1999; Wang and Ahmed, 2007), characteristics of the knowledge base (e.g., Bierly et al., 2009) and environmental factors such as location in a cluster (e.g., Camisón and Forés, 2011) and environmental turbulence (e.g., Lichtenthaler, 2009). We thank an anonymous reviewer for this valuable suggestion.

Sixth, this study examines the effect of internal knowledge creation capability and absorptive capability, both dynamic capabilities (Teece, 2007) aimed at the accumulation of new knowledge from internal and external sources of knowledge, respectively, on innovation performance. It would also be interesting to analyze the effect on innovation performance of coordination and cohesion capabilities (Camisón, 2005) aimed at refining and enhancing the existing knowledge base and capabilities. Such an analyzis may allow us to explain whether the direct effect of size on incremental innovation performance indirectly gathers the effect of these second-order capabilities (Wang and Ahmed, 2007) or coordination and cohesion capabilities. The results of Zhou and Li's (2012) study also suggest new avenues for future research. In this line, it would be interesting to analyze how the characteristics of the existing 
knowledge base could determine the firm's level of investment in the organizational components of absorptive capability and internal knowledge creation capability. It would also be of interest to analyze the extent to which it is useful to continue developing absorptive capability to obtain radical innovation performance and to bear the costs of searching, coordinating and integrating external knowledge, without hampering the build up of pathdependent knowledge stock within the firm.

The present study does not link the dependent variables to firms' financial performance. Further research connecting the use of different types of innovation performance with financial performance (Kostopoulos et al., 2011) (short- versus long-term performance) could estimate the benefits of such a hybrid innovation strategy. In this vein, it would also be interesting to consider different degrees of radicalness in the innovation performance, not only including innovations new to the firm, but also new to the firm's market (Cantner et al., 2011) or new to the world (Atuahene-Gima, 2005; Darroch, 2005). Results would allow drawing more precise conclusions on how firms should manage their innovation process than done in the present study. 


\section{REFERENCES}

Abernathy, W.J., \& Utterback, J.M. (1978). Patterns of innovation in Industry. Technology Review, 80(7), 40-47.

Alexander, D.L., Lynch Jr, J.G., \& Wang, Q. (2008). As time goes by: do cold feet follow warm intentions for really new versus incrementally new products? Journal of Marketing Research, 45(3), 307-319.

Anderson, J.C., \& Gerbing, D.W. (1982). Some methods for respecifying measurement models to obtain unidimensional constructs measures. Journal of Marketing Research, 19, 453-460.

Anderson, J.C., \& Gerbing, D.W. (1988). Structural equation modelling in practice: a review and recommended two-step approach. Psychology Bulletin, 103, 411-423.

Armstrong, J.S., \& Overton, T.S. (1977). Estimating nonresponse bias in mail surveys. Journal of Marketing Research, 14, 396-402.

Atuahene-Gima K. (2005). Resolving the capability-rigidity paradox in new product innovation. Journal of Marketing, 69, 61-83.

Beneito, P. (2003). Choosing among alternative technological strategies: an empirical analysis of formal sources of innovation. Research Policy, 32(4), 693-713.

Benner, M.J., \& Tushman, M.L. (2003). Exploitation, exploration, and process management: The productivity dilemma revisited. Academy of Management Review, 28(2), 238-256.

Benson, D., \& Ziedonis, R.H. (2009). Corporate venture capital as a window on new technologies: Implications for the performance of corporate investors when acquiring startups. Organization Science, 20(2), 329-351.

Bierly, P.E., \& Chakrabarti, A. (1996). Technological learning, strategic flexibility, and new product development in the pharmaceutical industry. IEEE Transactions on Engineering Management, 43(4), 368-380.

Bierly, P.E., Damanpour, F., \& Santoro, M. (2009). The application of external knowledge: organizational conditions for exploration and exploitation. Journal of Management Studies, 46(3), 481-509.

Blau, P.M., \& Schoenherr, R.A. (1971). The structure of organizations. New York: Basic Books.

Bontis, N., Crossan, M.M., \& Hulland, J. (2002). Managing an organizational learning system by aligning stocks and flows. Journal of Management Studies, 39(4), 437-469.

Burgelman, R.A. (2002). Strategy as vector and the inertia of coevolutionary lock-in. Administrative Science Quarterly, 47(2), 325-357. 
Camison, C. (2005). On how to measure managerial and organizational capabilities: multiitem models for measuring distinctive competences. Management Research: The Journal of the Iberoamerican Academy of Management, 3(1), 27-48.

Camisón, C., \& Forés, B. (2010). Knowledge absorptive capacity: new insights for its conceptualization and measurement. Journal of Business Research, 63(7), 707-715.

Camisón, C., \& Forés, B. (2011). Knowledge creation and absorptive capacity: the effect of intra-district shared competences. Scandinavian Journal of Management, 27(1), 66-86.

Camisón, C., Lapiedra, R., Segarra, M., \& Boronat, M. (2004). A meta-analysis of innovation and organizacional size. Organizacional Studies, 25(3), 331-361.

Cantner, U, Joel, K, \& Schmidt, T. (2011). The effects of knowledge management on innovative success: an empirical analysis of German firms. Research Policy, 40, 1453-1462.

Cassiman, B., \& Veugelers, R. (2006). In search of complementarity in innovation strategy: internal R\&D and external knowledge acquisition. Management Science, 52, 68-82.

Cepeda, G., \& Vera, D. (2007). Dynamic capabilities and operational capabilities: a knowledge management perspective. Journal of Business Research, 60, 426-437.

Chandy, R.K., \& Tellis, G.J. (2000). The incumbent's curse? Incumbency, size, and radical product innovation. Journal of Marketing, 64(3), 1-17.

Chandy, R.K., \& Tellis, G.J. (1998). Organizing for radical product innovation: The overlooked role of willingness to cannibalize. Journal of Marketing Research, 35, 120-132.

Chesbrough, H. (2006). Open innovation: a new paradigm for understanding industrial innovation. In: H. Chesbrough, W. Vanhaverbeke, \& J. West (Eds.), Open innovation: researching a new paradigm (pp. 1-12). New York: Oxford University Press.

Chiang, Y.-H., \& Hung, K.-P. (2010). Exploring open search strategies and perceived innovation performance from the perspective of inter-organizational knowledge flows. $R \& D$ Management, 40, 292-299.

Churchill Jr, G.A. (1979). A paradigm for developing better measures of marketing constructs. Journal of Marketing Research, 16(1), 64-73.

Cohen, W.M., \& Levinthal, D.A. (1990). Absorptive capacity: a new perspective on learning and innovation. Administrative Science Quarterly, 35, 128-152.

Cooper, R. G., \& de Brentani, U. (1991). New industrial financial services: what distinguishes the winners. Journal of Product Innovation Management, 8(2), 75-90.

Creswell, J.W. (2003). Research design. Qualitative, quantitative and mixed methods approaches. Thousand Oaks, Sage. 
Damanpour, F. (1991). Organizational innovation: a meta-analysis of effects of determinants and moderators. Academy of Management Journal, 34(3), 555-590.

Damanpour, F. (1992). Organizational size and innovation. Organization Studies, 13(3), 375 402.

Damanpour, F., \& Wischnevsky, D.J. (2006). Research on innovation in organizations: distinguishing innovation-generating from innovation-adopting organizations. Journal of Engineering and Technology Management, 23(4), 269-291.

Danneels, E. (2008). Organizational antecedents of second-order competences. Strategic Management Journal, 29(5), 519-543.

Darroch J. (2005). Knowledge management, innovation and firm performance. Journal of Knowledge Management, 9(3), 101-115

Denford, J.S. (2013). Building knowledge: developing a knowledge-based dynamic capabilities typology. Journal of Knowledge Management, 17(2), 175-194.

Denzin, N.K. (1978). The research act: A theoretical introduction to sociological methods. New York, McGraw-Hill.

Dess, G.S., \& Beard, D.W. (1984). Dimensions of organizational task environments. Administrative Science Quarterly, 29, 52-73.

Dewar, R.D., \& Dutton, J.E. (1986). The adoption of radical and incremental innovations: an empirical analysis. Management Science, 31(11), 1422-1433.

Dougherty, D., \& Hardy, C. (1996). Sustained product innovation in large, mature organizations: Overcoming innovation-to-organization problems. Academy of Management Journal, 39(5), 1120-1153.

Easterby-Smith, M., Crossan, M., \& Nicolini, D. (2000). Organizational learning: debates past, present, and future. Journal of Management Studies, 37(6), 783-96.

Eisenhardt, K.M., \& Martin, J.A. (2000). Dynamic capabilities: what are they? Strategic Management Journal, 21(10-11), 1105-1121.

Ellonen, H.K., Wikström, P., \& Jantunen, A. (2009). Linking dynamic capability portfolios and innovation outcomes. Technovation, 29, 753-762.

Escribano, A., Fosfuri, A., \& Tribó, J.A. (2009). Managing external knowledge flows: the moderating role of absorptive capacity. Research Policy, 38(1), 96-105.

Ettlie, J.E., \& Rubenstein, A.H. (1987). Firm size and product innovation. Journal of Product Innovation Management, 4(2), 89-108.

Ettlie, J.E., Bridges, W.P., \& O’keefe, R.D. (1984). Organization strategy and structural differences for radical versus incremental innovation. Management Science, 30(6), 682-695. 
Farjoun, M. (2010). Beyond dualism: stability and change as a duality. Academy of Management Review, 35(2), 202-225.

Forsman, H. (2011). Innovation capacity and innovation development in small enterprises. A comparison between the manufacturing and service sectors. Research Policy, 40, 739-750.

Forsman, H., \& Annala, U. (2011). Small enterprises as innovators. The shift from a low performer to a high performer. International Journal of Technology Management, 56(1/2).

García Morales, V.J., Llórens-Montes, F.J., \& Verdú-Jover, A.J. (2007). Influence of personal mastery on organizational performance through organizational learning and innovation in large forms and SMEs. Technovation, 27, 547-568.

García, R., \& Calantone R. (2002). A critical look at technological innovation typology and innovativeness terminology: a literature review. Journal of Product Innovation Management, $19,110-132$.

Germain, R. (1996). The role of context and structure in radical and incremental logistics innovation adoption. Journal of Business Research, 35, 117-127.

Goh, S., \& Richards, G. (1997). Benchmarking the learning capacity of organizations. European Management Journal, 15(5), 575-583.

Grant, R.M. (2000). Shifts in the world economy: the driver of knowledge management. In: Despres. C., Chauvel, D. (eds.), Knowledge horizons: the present and the promise of knowledge management. Oxford, Butterworth-Heineman.

Gupta, A.K., Smith, K.G., \& Shalley, C.E. (2006). The interplay between exploration and exploitation. Academy of Management Journal, 49, 693-706.

Hair, J.F., Anderson, R.E., Tatham, R., \& Black, W. (1998). Multivariate data analysis. Homewood, Prentice Hall.

Haveman, H.A. (1992). Between a rock and a hard place: Organizational change and performance under conditions of fundamental environmental transformation. Administrative Science Quarterly, 37, 48-75.

He, Z.L., \& Wong, P.K. (2004). Exploration vs. exploitation: an empirical test of the ambidexterity hypothesis. Organization Science, 15(4), 481-494.

Helfat, C.E., \& Peteraf, M.A. (2003). The dynamic resource-based view: capability lifecycles. Strategic Management Journal, 24(10), 997-1010.

Hernandez-Espallardo, M., Molina-Castillo, F.J., \& Rodriguez-Orejuela, A. (2012). Learning processes, their impact on innovation performance and the moderating role of radicalness. European Journal of Innovation Management, 15(1), 77-98. 
Herrmann, A., Gassmann, O., \& Ultich, E. (2007). An empirical study of the antecedents for radical product innovations and capabilities for transformation. Journal of Engineering and Technology Management, 24, 92-120.

Howells, J., James, A., \& Malik, K. (2003). The sourcing of technological knowledge: distributed innovation processes and dynamic change. $R \& D$ Management, 33(4), 395-409.

Jick, T.D. (1979). Mixing qualitative and quantitative methods: Triangulation in action. Administrative Science Quarterly, 24, 602-610.

Jiménez-Barrionuevo, M.M., García-Morales, V.J., \& Molina, L.M. (2011). Validation of an instrument to measure absorptive capacity. Technovation, 31(5), 190-202.

Jiménez-Jiménez, D., \& Sanz-Valle, R. (2011). Innovation, organizational learning, and performance. Journal of Business Research, 64, 408-417.

Kessler, E.H., Bierly, P.E., \& Gopalakrishnan, S. (2000). Internal vs. external learning in new product development: effects on speed, costs and competitive advantage. $R \& D$ Management, $30(3), 213-224$

Kim, C., Song, J., \& Nerkar, A. (2012). Learning and innovation: exploitation and exploration trade-offs. Journal of Business Research, 65, 1189-1194.

Knoppen, D., Sáenz, M.J., \& Johnston, D.A. (2011). Innovations in a relational context: mechanism to connect learning processes of absorptive capacity. Management Learning, 31, 419-438.

Koberg, C., Detienne, D., \& Heppard, K. (2003). An empirical test of environmental, organizational, and process factors affecting incremental and radical innovation. Journal of High Technology, 14, 21-45.

Kogut, B., \& Zander, U. (1992). Knowledge of the firm, combinative capabilities, and the replication of technology. Organization Science, 3, 383-397.

Kostopoulos, K., Papalexandris, A., Papachroni, M., \& Ioannou, G. (2011). Absorptive capacity, innovation, and financial performance. Journal of Business Research, 64(12), 13351343.

Lane, P.J., Koka, B.R., \& Pathak, S. (2006). The reification of absorptive capacity: a critical review and rejuvenation of the construct. Academy of Management Review, 31(4), 833-863.

Laursen, K. \& Salter, A.J. (2006). Open for innovation: the role of openness in explaining innovative performance among UK manufacturing firms. Strategic Management Journal, 27(2), 131-150.

Lavie, D. (2006). The competitive advantage of interconnected firms: an extension of the Resource-Based View. Academy of Management Review, 31(3), 638-658. 
Leiblein, M.J., \& Madsen, T.L. (2009). Unbundling competitive heterogeneity: incentive structures and capability influences on technological innovation. Strategic Management Journal, 30, 711-735.

Levinthal, D.A., \& March, J.G. (1993). The myopia of learning. Strategic Management Journal, 14, 95-112.

Li, Y., Liu, Y., Li, M., \& Wu, H. (2008). Transformational offshore outsourcing: empirical evidence from alliances in China. Journal of Operations Management, 26(2), 257-274.

Liao, S-H., Fei, W-C., \& Chen, C-C. (2007). Knowledge sharing, absorptive capacity, and innovation capability: an empirical study of Taiwan's knowledge-intensive industries, Journal of Information Science, 20, 1-20.

Lichtenthaler, U. (2009). Absorptive capacity, environmental turbulence, and the complementarity of organizational learning process. Academy of Management Journal, 52(4), 822-846.

Lichtenthaler, U., \& Lichtenthaler, E. (2009). A capability-based framework for open innovation: complementing absorptive capacity. Journal of Management Studies, 46(8), 13151338.

Lim, K. (2009). The many faces of absorptive capacity: spillovers of cooper interconnect technology for semiconductor chips. Industrial and Corporate Change, 18(6), 1249-1284.

March, J. G. (1991). Exploration and exploitation in organizational learning. Organization Science, 2(1), 71-87.

Meyers, P. W., \& Tucker, F. G. (1989). Defining roles for logistics during routine and radical technological innovation. Journal of the Academy of Marketing Science, 17(1), 73-82.

Song, X.M., \& Montoya-Weiss, M.M. (1998). Critical development activities for really new versus incremental products. Journal of Product Innovation Management, 15(2), 124-135.

Nonaka, I., \& Von Krogh, G. (2009). Perspective-tacit knowledge and knowledge conversion: controversy and advancement in organizational knowledge creation theory. Organization Science, 20(3), 635-652.

Nonaka, I., Toyama, R., \& Nagata, A. (2000). A firm as a knowledge-creating entity: a new perspective on the theory of the firm. Industrial and Corporate Change, 9(1), 1-20.

Nonaka, I. (1994). A dynamic theory of organizational knowledge creation. Organization Science, 5, 14-37.

Nooteboom, B., Van Haverbeke, W., Duysters, G., Gilsing, V., \& Van den Oord, A. (2007). Optimal cognitive distance and absorptive capacity. Research Policy, 36, 1016-1034. 
O’Reilly, C.A., \& Tushman, M.L. (2008). Ambidexterity as a dynamic capability: resolving the innovator's dilemma. In A. P. Brief, \& B. M. Staw (Eds.), Research in Organizational Behavior 28 (pp. 185-206). Oxford: Elsevier.

OECD (2005). Oslo Manual: Guidelines for collecting and interpreting innovation Data. Paris: OECD.

Pavitt, K. (1990). What we know about the strategic management of technology. California Management Review, 23(3), 17-26

Podsakoff, P.M., MacKenzie, S.B., Lee, J.Y., \& Podsakoff, N.P. (2003). Common method biases in behavioral research: a critical review of the literature and recommended remedies. Journal of Applied Psychology, 88(5), 879-903.

Podsakoff, P.M., \& Organ, D.W. (1986). Self-reports in organizational research: problems and prospects. Journal of Management, 12(2), 531-544.

Porter, M.E. (1985). Competitive advantage: creating and sustaining superior performance. New York: Free Press.

Probst, G., \& Raisch, S. (2005). Organizational crisis: the logic of failure. The Academy of Management Executive, 19(1), 90-105.

Purvis, R.L., Sambamurthy, V., \& Zmud, R.W. (2001). The assimilation of knowledge platforms in organizations: an empirical investigation. Organization Science, 12(2), 117-135.

Ritala P., \& Hurmelinna-Laukkanen, P. (2012). Incremental and radical innovation in coopetition: the role of absorptive capacity and appropriability. Journal of Product Innovation Management (in press).

Rivkin, J.W. (2001). Reproducing knowledge: replication without imitation at moderate complexity. Academy of Management Journal, 12(3), 274-293.

Rosenkopf, L., \& Nerkar, A. (2001). Beyond local search: boundary-spanning, exploration, and impact in the optical disk industry. Strategic Management Journal, 22(4), 287-306.

Rothaermel, F.T., \& Alexandre, M.T. (2009). Ambidexterity in technology sourcing: the moderating role of absorptive capacity. Organizational Sciences, 20(4), 759-780.

Rothwell, R. (1983). Innovation and firm size- a case for dynamic complementarity-or, is small really so beautiful. Journal of General Management, 8(3), 5-25.

Santamaría, L, Nieto, M.J., \& Barge-Gil, A. (2009). Beyond formal R\&D: taking advantage of other sources of innovation in low-and medium- technology industries. Research Policy, $38,507-517$.

Satorra, A., \& Bentler, P.M. (1994). Corrections to test statistics and standard error in covariance structure analysis. In A. Von Eye, \& C.C. Clogg (Eds.), Latent variables analysis: applications for developmental research. Thousand Oaks: Sage. 
Schoenmakers, W., \& Duysters, G. (2010). The technological origins of radical inventions. Research Policy, 39, 1051-1059.

Simsek, Z., \& Veiga, J.F. (2001). A primer on Internet self-administered surveys. Organizational Research Methods Journal, 4, 218-235.

Smith, K. G., Collins, C.J. \& Clark, K.D. (2005). Existing knowledge, knowledge creation capability, and the rate of new product introduction in high-technology firms. Academy of Management Journal, 48, 346-57.

Soosay, C., Hyland, P., \& Ferrer, M. (2008). Supply chain collaboration: capabilities for continuous innovation. Supply Chain Management: An International Journal, 13(2), 160-169.

Sorensen, J.B., \& Stuart, T.E. (2000). Age, obsolescence, and organizational innovation. Administrative Science Quarterly, 45(1), 81-112.

Stanton, J. M., \& Rogelberg, S. G. (2001). Using Internet/Intranet web pages to collect organizational research data. Organizational Research Methods, 4(3), 200-217.

Staples, D.S., Greenaway, K., \& McKeen, J.D. (2001). Opportunities for research about managing the knowledge-based enterprise. International Journal of Management Reviews, $3(1), 1-20$.

Subramaniam, M., \& Youndt, M. (2005). The influence of intelectual capital on the types of innovative capabilities. Academy of Management Journal, 48(3), 450-463.

Teece, D.J. (2007). Explicating dynamic capabilities: the nature and microfoundations of (sustainable) enterprise performance. Strategic Management Journal, 28(13), 1319-1350.

Templeton G.F., Lewis B.R., \& Snyder C.A. (2002). Development of a measure for the organizational learning construct. Journal Management Information System, 19(2), 175-218.

Todorova, G., \& Durisin, B. (2007). Absorptive capacity: valuing a reconceptualization. Academy of Management Review, 32(3), 774-786.

Tödtling, F., Lehner, P., \& Kaufmann, A. (2009). Do different types of innovation rely on specific kinds of knowledge interactions. Technovation, 29, pp. 59-71.

Tsai, K-H., \& Wang, J-C. (2005). Does R\&D performance decline with firm size? A reexamination in terms of elasticity. Research Policy, 34, 966-976.

Tushman, M. L., \& O'Reilly, C.A. (1997). Winning through innovation: A practical guide to leading organizational change and renewal. Boston: Harvard Business School Press.

Uotila, J., Maula, M., Keil, T., \& Zahra, S.A. (2009). Exploration, exploitation, and financial performance: analysis of S\&P 500 corporations. Strategic Management Journal, 30, 221-231. 
Van Den Bosch, F.A., Volberda, H.W., \& De Boer, M. (1999). Coevolution of firm absorptive capacity and knowledge environment: Organizational forms and combinative capabilities. Organization Science, 10(5), 551-568.

van Wijk, R., Jansen, J., \& Lyles, M. (2008). Inter- and intra-organizational knowledge transfer: a meta-analytic review and assessment of its antecedents and consequences. Journal of Management Studies, 45(4), 830-853.

Vega-Jurado, J., Gutiérrez-Gracia, A., Fernández-de-Lucio, I., \& Manjarrés-Herníquez, L. (2008). The effect of external and internal factors on firms' product innovation. Research Policy, 37, 616-632.

Volberda, H.W., Foss, N.J., \& Lyles, M.A. (2010). Perspective-Absorbing the concept of absorptive capacity: how to realize its potential in the organization field. Organization Science, 21(4), 931-951.

Wang, C.L., \& Ahmed, P. (2007). Dynamic capabilities: a review and research agenda. International Journal of Management Reviews, 9(1), 31-51.

Zack, M.H. (1999). Managing codified knowledge. Sloan Management Review, 40(4), 45-58.

Zahra, S.A., \& George, G. 2002. Absorptive capacity: a review, reconceptualization, and extension. Academy of Management Review, 27(2), 185-203.

Zhou, K.Z., \& Li, C. B. (2012). How knowledge affects radical innovation: knowledge base, market knowledge acquisition, and internal knowledge sharing. Strategic Management Journal, 33, 1090-1102.

Zhou, K.Z., \& Li, C.B. (2010). How strategic orientations influence the building of dynamic capability in emerging economies. Journal of Business Research, 63(3), 224-231.

Zhou, K.Z., \& Wu, F. 2010. Technological capability, strategic flexibility, and product innovation. Strategic Management Journal, 31, 547-561.

Zollo, M., \& Winter, S.G. (2002). Deliberate learning and the evolution of dynamic capabilities. Organization Science, 13(3), 339-351.

Zott, C. (2003). Dynamic capabilities and the emergence of intraindustry differential firm performance: insights from a simulation study. Strategic Management Journal, 24(2), 97125.Arias-Aranda, D., Minguela-Rata, B., \& Rodríguez-Duarte, A. (2001). Innovation and firm size: an empirical study for Spanish engineering consulting companies. European Journal of Innovation Management, 4(3), 133-142.

Baldridge, J. V., \& Burnham, R. A. (1975). Organizational innovation: Individual, organizational, and environmental impacts. Administrative Science Quarterly, 165-176.

Cáceres, R., Guzmán, J., \& Rekowski, M. (2011). Firms as source of variety in innovation: influence of size and sector. International Entrepreneurship and Management Journal, 7(3), 357-372. 
Laforet, S. (2008). Size, strategic, and market orientation affects on innovation. Journal of Business Research, 61(7), 753-764.

Laforet, S. (2013). Organizational innovation outcomes in SMEs: Effects of age, size, and sector. Journal of World Business, 48(4), 490-502.

Flatten, T. C., Greve, G. I., \& Brettel, M. (2011). Absorptive capacity and firm performance in SMEs: The mediating influence of strategic alliances. European Management Review, 8(3), 137-152.

Jones, G. R., \& Butler, J. E. (1992). Managing internal corporate entrepreneurship: An agency theory perspective. Journal of Management, 18(4), 733-749.

Vaccaro, I. G., Jansen, J. J., Van Den Bosch, F. A., \& Volberda, H. W. (2012). Management innovation and leadership: the moderating role of organizational size. Journal of Management Studies, 49(1), 28-51. 


\section{Figure 1. Theoretical Model ${ }^{b}$}

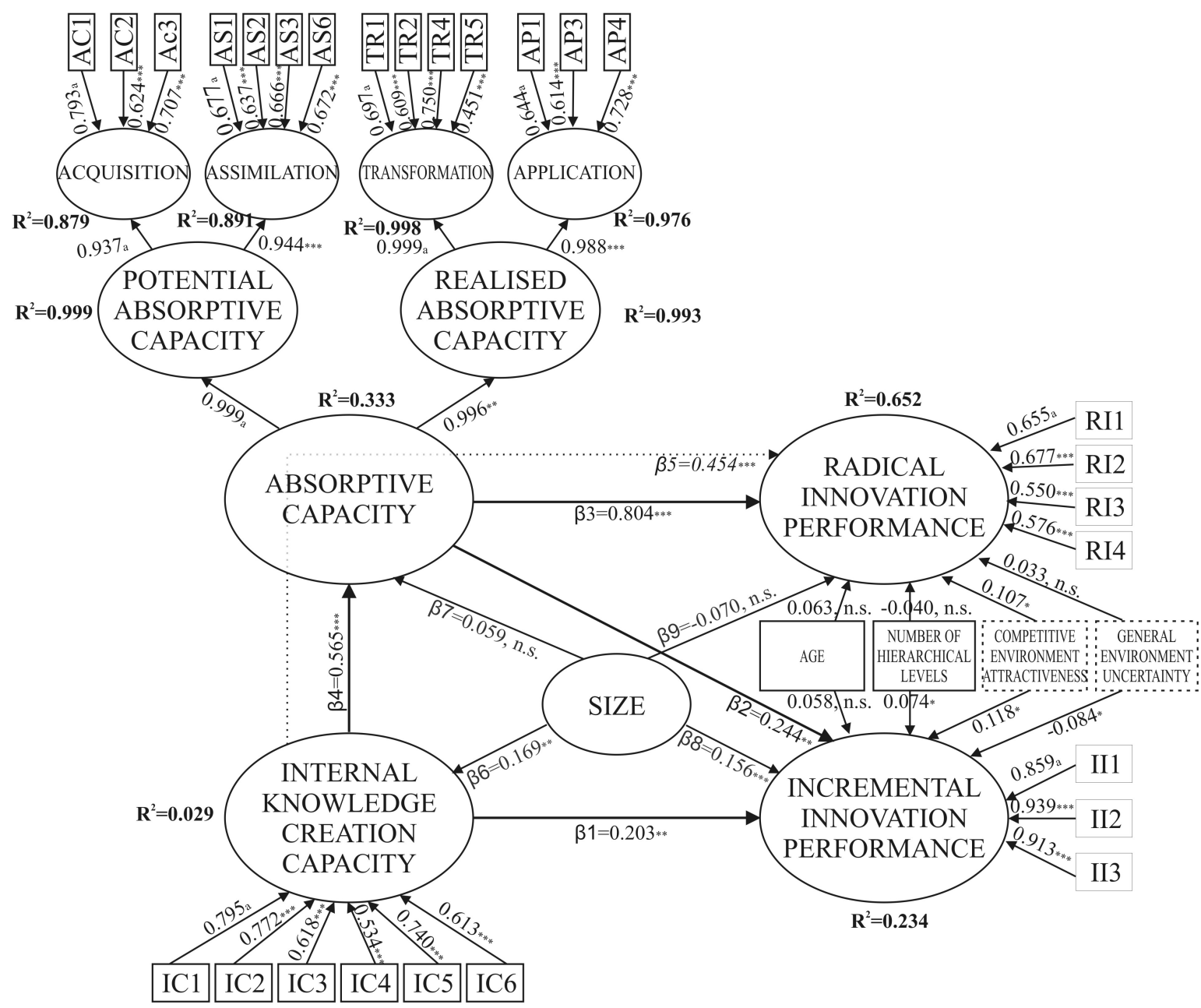

$\chi^{2}=452.4609 ;$ d.f. $=445 ; \mathrm{p}=0.393 ; \mathrm{BB}-\mathrm{NNFI}=0.997 ; \mathrm{CFI}=0.998 ; \mathrm{IFI}=0.998 ; \mathrm{MFI}=0.988 ; \mathrm{NC}=1.017$; RMSEA $=0.007$

${ }^{\text {a }}$ Parameter equal to one to determine the scale of the latent construct

${ }^{\mathrm{b}}$ See annexes for a full description of the items

$* \mathrm{p}<.05 ; * * \mathrm{p}<.01, * * * \mathrm{p}<0.001$ 
Figure 2. No relationship between internal knowledge creation capability and absorptive capability

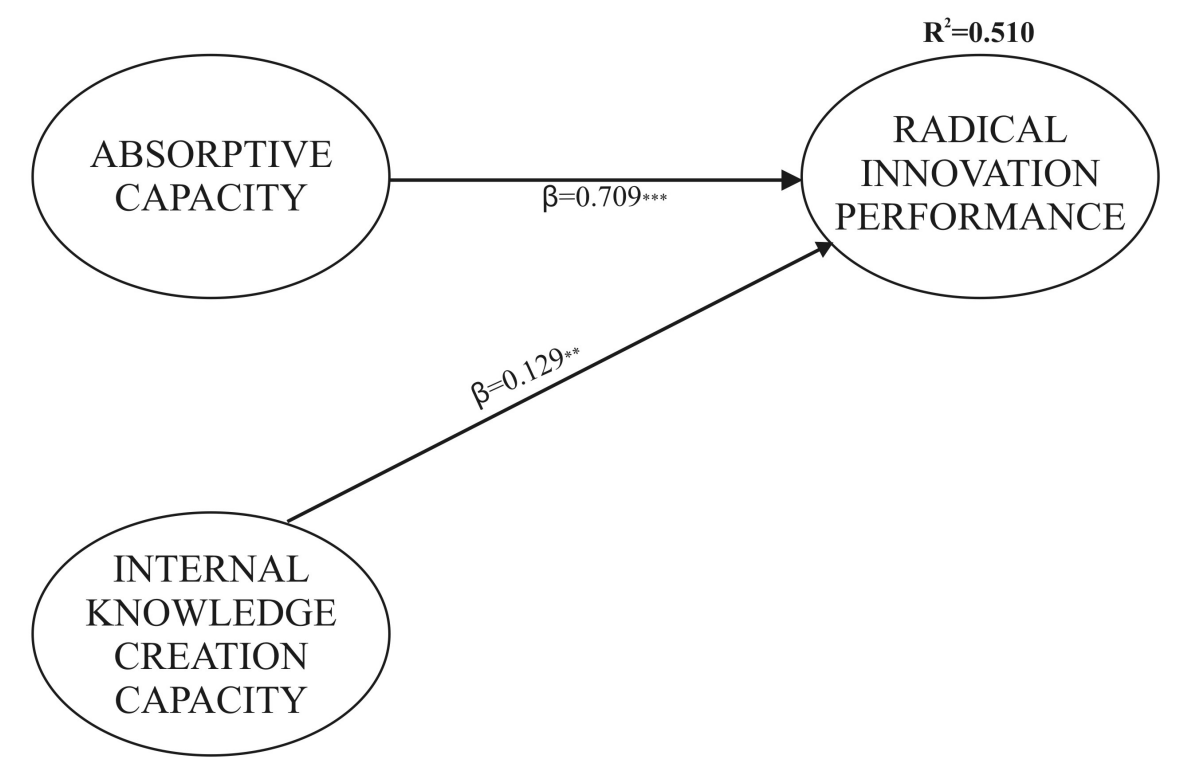

$\chi^{2}=400.2918 ;$ d.f. $=237$; BB-NNFI $=.0936 ; \mathrm{CFI}=0.937 ; \mathrm{IFI}=0.937 ; \mathrm{NC}=1.689 ; \mathrm{RMSEA}=0.042$

$* \mathrm{p}<.05 ; * * \mathrm{p}<.01, * * * \mathrm{p}<0.001$ 
Figure 3. Direct and indirect effect of internal knowledge creation capability on radical innovation performance

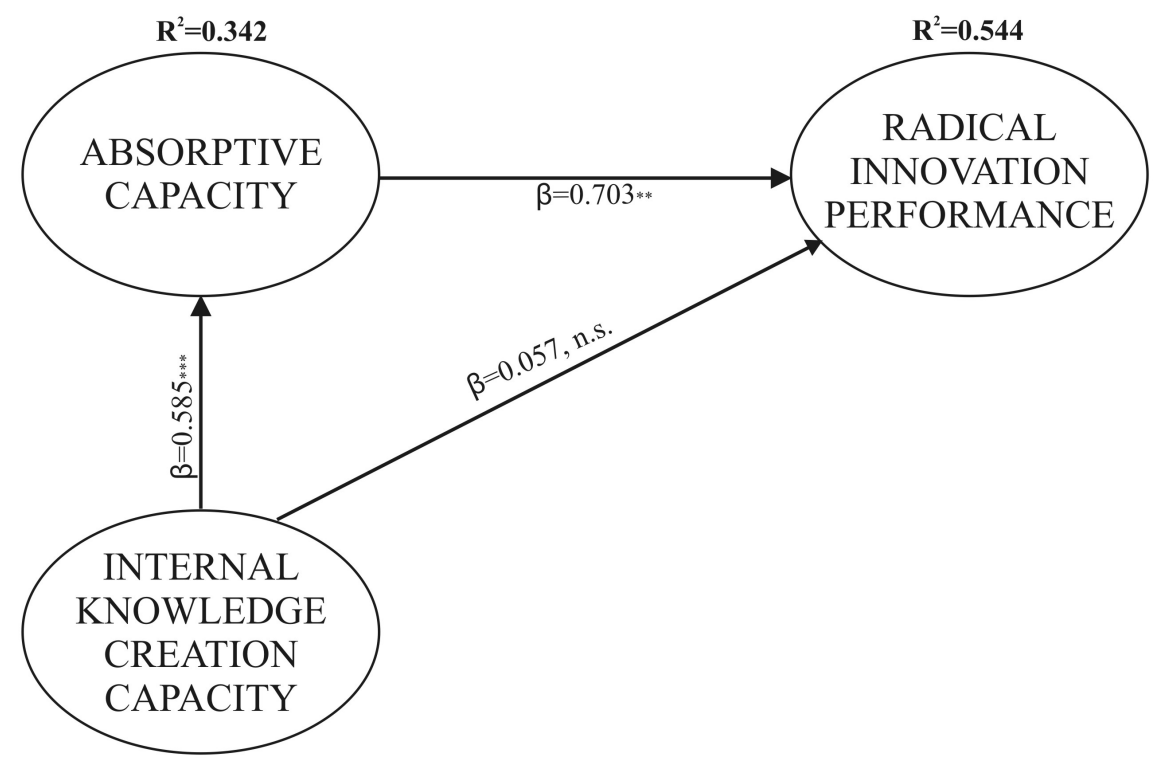

$\chi^{2}=284.4202 ;$ d.f. $=236 ;$ BB-NNFI $=.0978 ; \mathrm{CFI}=0.981 ; \mathrm{IFI}=0.981 ; \mathrm{NC}=1.205 ; \mathrm{RMSEA}=0.023$

${ }^{*} \mathrm{p}<.05 ; * \mathrm{p}<.01, * * * \mathrm{p}<0.001$

Figure 4. Indirect effect of internal knowledge creation capability on radical innovation performance

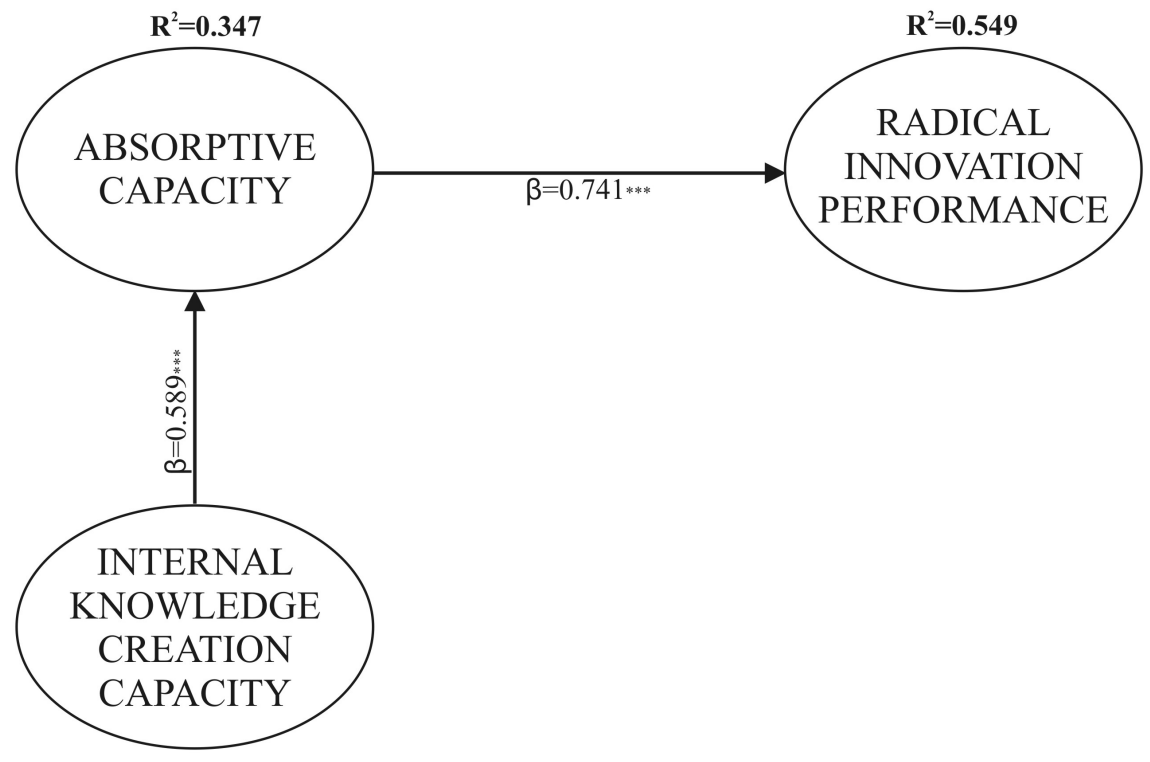

$\chi^{2}=240.4885 ;$ d.f. $=237 ; \mathrm{BB}-\mathrm{NNFI}=.998 ; \mathrm{CFI}=0.999 ; \mathrm{IFI}=0.999 ; \mathrm{NC}=1.02 ; \mathrm{RMSEA}=0.006$

$* \mathrm{p}<.05 ; * * \mathrm{p}<.01, * * * \mathrm{p}<0.001$ 
Figure 5 Alternative conceptual model: a partially mediating model

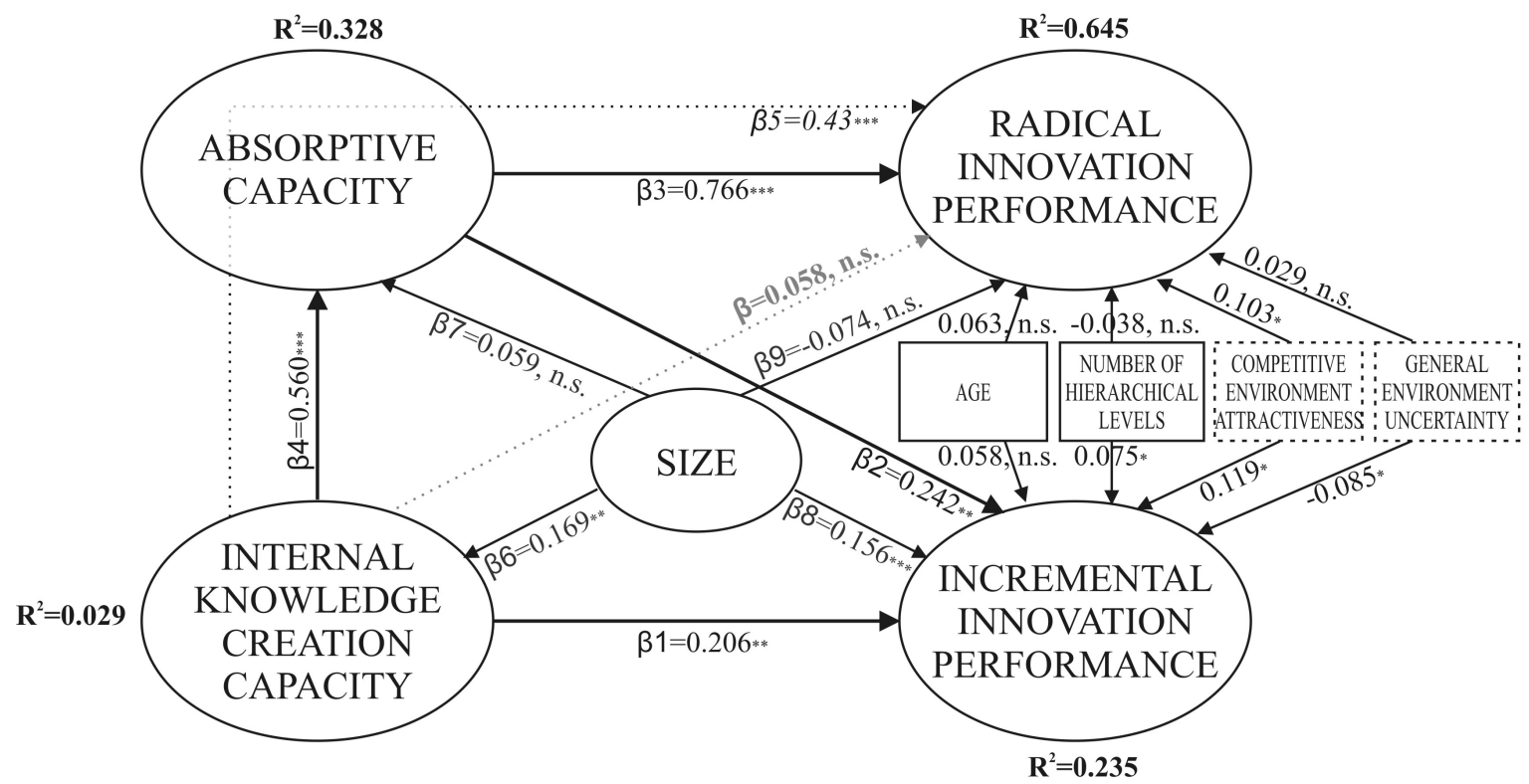

$\chi^{2}=459.72 ;$ d.f. $=444 ; \mathrm{BB}-\mathrm{NNFI}=.995 ; \mathrm{CFI}=0.995 ; \mathrm{IFI}=0.995 ; \mathrm{NC}=1.035 ; \mathrm{RMSEA}=0.011$

$* \mathrm{p}<.05 ; * * \mathrm{p}<.01,{ }^{* * *} \mathrm{p}<0.001$ 


\section{TABLES}

Table 1. Definition of the constructs included in the conceptual model and their dimensions

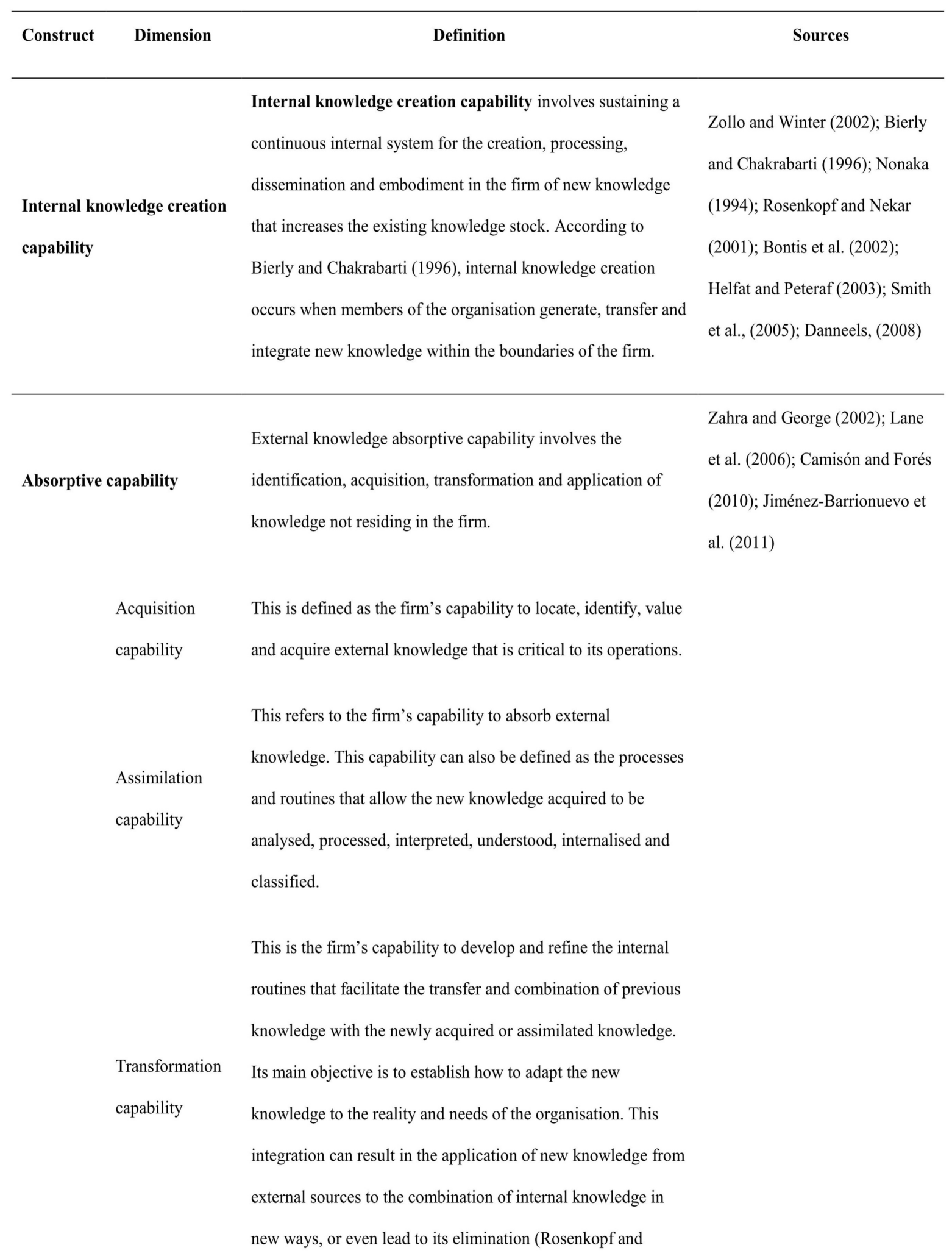


Nekar, 2001; Lane et al., 2006; Danneels, 2008). A firm’s

ability to recombine and utilise its current knowledge base in

novel ways is what Kogut and Zander (1992) define as

combinative capabilities.

This refers to the firm's capability to use new knowledge, for commercial ends, to achieve its objectives. This capability can also be defined as the organisational capability based on

Application routines that enable firms to incorporate acquired, assimilated

capability and transformed knowledge into their operations and routines

not only to refine, expand and leverage existing capabilities,

whether general, scientific, technical or organisational, but also

to create new capabilities and/or solutions to existing problems.

Radical innovation

performance

fundamental changes in the firm's products, processes,

technologies and organisational structure and methods.
Meyers and Tucker (1989);

Dewar and Dutton (1986); Song

and Montoya-Weiss, (1998);

Oslo Manual (2005)

Incremental innovation performance entails the refinement and reinforcement of existing products, processes, technologies,

organisational structure and methods.
Dosi (1989); Chandy and Tellis

(1998); Oslo Manual, (2005) 
Table 2. Means, standard deviations and correlations among study variables

\begin{tabular}{|c|c|c|c|c|c|c|c|c|c|c|c|c|c|c|}
\hline & Variable & Mean & SD & 1 & 2 & 3 & 4 & 5 & 6 & 7 & 8 & 9 & 10 & 11 \\
\hline 1 & Internal knowledge creation capability & 3.489 & 0.561 & 1.00 & & & & & & & & & & \\
\hline 2 & Absorptive capability & 3.216 & 0.603 & $0.565^{* *}$ & 1.00 & & & & & & & & & \\
\hline 3 & Potential absorptive capability & 3.186 & 0.637 & $0.526 * *$ & $0.945^{* *}$ & 1.00 & & & & & & & & \\
\hline 4 & Realised absorptive capability & 3.246 & 0.639 & $0.542 * *$ & $0.945^{* *}$ & $0.786^{* *}$ & 1.00 & & & & & & & \\
\hline 5 & Acquisition capability & 3.142 & 0.712 & $0.438 * *$ & $0.866^{* *}$ & $0.908^{* *}$ & $0.729^{* *}$ & 1.00 & & & & & & \\
\hline 6 & Assimilation capability & 3.231 & 0.695 & $0.516 * *$ & $0.845^{* *}$ & $0.903 * *$ & $0.694 * *$ & $0.641^{* *}$ & 1.00 & & & & & \\
\hline 7 & Transformation capability & 3.256 & 0.660 & $0.590 * *$ & $0.866^{* *}$ & $0.730^{* *}$ & $0.906^{* *}$ & $0.655^{* *}$ & $0.667^{* *}$ & 1.00 & & & & \\
\hline 8 & Application capability & 3.236 & 0.736 & $0.412 * *$ & $0.866 * *$ & $0.710^{* *}$ & $0.925^{* *}$ & $0.678^{* *}$ & $0.608^{* *}$ & $0.676^{* *}$ & 1.00 & & & \\
\hline 9 & Incremental innovation performance & 2.880 & 1.038 & $0.385^{* *}$ & $0.383^{* *}$ & $0.360^{* *}$ & $0.369^{* *}$ & $0.290^{* *}$ & $0.365^{* *}$ & $0.387^{* *}$ & $0.297 * *$ & 1.000 & & \\
\hline 10 & Radical innovation performance & 3.444 & 0.696 & $0.389 * *$ & $0.591 * *$ & $0.580^{* *}$ & $0.537 * *$ & $0.469 * *$ & $0.584 * *$ & $0.500^{* *}$ & $0.484^{* *}$ & $0.293 * *$ & 1.000 & \\
\hline 11 & Size & 48.82 & 58.648 & $0.157 * *$ & $0.169^{* *}$ & $0.144 * *$ & $0.176^{* *}$ & $0.115=$ & $0.147 * *$ & $0.211 * *$ & $0.117^{*}$ & $0.247^{* *}$ & 0.049 & 1.00 \\
\hline
\end{tabular}

$* \mathrm{p}<.05 ; * * \mathrm{p}<.01$ 
Table 3. Confirmatory Factor Analyzis of the construct measurement model ${ }^{\mathrm{a}}$

\begin{tabular}{|c|c|c|c|c|c|}
\hline Factors & $\begin{array}{c}\text { Standardised } \\
\text { factor } \\
\text { loadings }\end{array}$ & $\begin{array}{c}\mathbf{t} \\
\text { values }^{\mathrm{c}}\end{array}$ & $\mathbf{R}^{2}$ & $\begin{array}{l}\text { Conjoint } \\
\text { reliability }\end{array}$ & $\begin{array}{c}\text { Goodness of fit } \\
\text { indexes of the } \\
\text { individual } \\
\text { measurement } \\
\text { scales }^{\text {d }}\end{array}$ \\
\hline $\begin{array}{l}\text { Internal knowledge creation } \\
\text { capability }\end{array}$ & & & & \multirow[t]{7}{*}{0.791} & \multirow{7}{*}{$\begin{array}{l}\text { BBNFI }=0.956 \\
\text { BBNNFI }=0.950 \\
\text { CFI }=0.970 \\
\text { IFI }=0.970 \\
\text { MFI }=0.978 \\
\text { RMSEA }=0.071 \\
{[0.041,0.103]} \\
\chi^{2}=26.988 ; \\
\text { d.f. }=9 ; p=0.001 \\
\alpha=0.825\end{array}$} \\
\hline IC1 & $0.822^{\mathrm{a}}$ & & 0.676 & & \\
\hline $\mathrm{IC} 2$ & 0.785 & 14.496 & 0.617 & & \\
\hline IC3 & 0.615 & 10.099 & 0.378 & & \\
\hline $\mathrm{IC} 4$ & 0.525 & 8.164 & 0.275 & & \\
\hline IC5 & 0.741 & 13.175 & 0.549 & & \\
\hline IC6 & 0.558 & 8.797 & 0.312 & & \\
\hline Absorptive capability & & & & 0.994 & $\begin{array}{l}\text { BBNFI }=0.920 \\
\text { BBNNFI }=0.965 \\
\text { CFI }=0.972 \\
\text { IFI }=0.973 \\
\text { MFI }=0.957 \\
\text { RMSEA }=0.035 \\
{[0.019,0.048]} \\
\chi^{2}=106.267 ; \\
\text { d.f. }=72 ; p=0.006 \\
\alpha=0.894\end{array}$ \\
\hline Potential absorptive capability & $0.998^{\mathrm{a}}$ & & 0.999 & 0.840 & $\begin{array}{l}\text { BBNFI }=0.961 \\
\text { BBNNFI }=0.980 \\
\text { CFI }=0.988 \\
\text { IFI }=0.988 \\
\text { MFI }=0.993 \\
\text { RMSEA }=0.033 \\
{[0.000,0.064]} \\
\chi^{2}=18.441 ; \\
\text { d.f. }=13 ; p=0.142 \\
\alpha=0.824\end{array}$ \\
\hline Realised absorptive capability & 0.994 & 46.390 & 0.982 & 0.928 & $\begin{array}{l}\text { BBNFI }=0.966 \\
\text { BBNNFI }=0.982 \\
\text { CFI }=0.989 \\
\text { IFI }=0.989 \\
\text { MFI }=0.993 \\
\text { RMSEA }=0.034 \\
{[0.000,0.065]} \\
\chi^{2}=18.734 ; \\
\text { d.f. }=13 ; p=0.132 \\
\alpha=0.805\end{array}$ \\
\hline Acquisition capability* & \multicolumn{2}{|l|}{$0.966^{\mathrm{a}}$} & 0.933 & \multirow[t]{4}{*}{0.683} & $\begin{array}{l}\text { BBNFI }=0.984 \\
\text { BBNNFI }=0.987\end{array}$ \\
\hline $\mathrm{AC} 1$ & $0.808^{\mathrm{a}}$ & & 0.653 & & $\begin{array}{l}\mathrm{CFI}=0.996 \\
\mathrm{IFI}=0.996\end{array}$ \\
\hline $\mathrm{AC} 2$ & 0.605 & 2.303 & 0.366 & & $\begin{array}{l}\text { MFI }=0.999 \\
\text { RMSEA }=0.029 \\
{[0.000,0.108]}\end{array}$ \\
\hline $\mathrm{AC} 3$ & 0.709 & 2.175 & 0.503 & & $\begin{array}{l}\chi^{2}=2.676 \\
\text { d.f. }=2 ; p=0.262 \\
\alpha=0.670\end{array}$ \\
\hline Assimilation capability & 0.912 & 3.114 & 0.832 & \multirow[t]{5}{*}{0.701} & $\begin{array}{l}\text { BBNFI }=0.991 \\
\text { BBNNFI }=0.992\end{array}$ \\
\hline AS 1 & $0.671^{\mathrm{a}}$ & & 0.451 & & $\begin{array}{l}\mathrm{CFI}=0.997 \\
\mathrm{IFI}=0.997\end{array}$ \\
\hline AS2 & 0.631 & 11.428 & 0.398 & & MFI $=0.999$ \\
\hline AS3 & 0.663 & 12.385 & 0.439 & & RMSEA $=0.032$ \\
\hline AS6 & 0.683 & 11.123 & 0.466 & & $\begin{array}{l}{[0.000,0.109]} \\
\chi^{2}=2.805\end{array}$ \\
\hline
\end{tabular}




\begin{tabular}{|c|c|c|c|c|c|c|c|}
\hline & & & & & & & $\begin{array}{l}\text { d.f. }=2 ; p=0.246 \\
\alpha=0.731\end{array}$ \\
\hline \multicolumn{3}{|c|}{ Transformation capability } & $0.996^{\mathrm{a}}$ & & 0.999 & 0.679 & $\begin{array}{l}\text { BBNFI }=0.984 \\
\text { BBNNFI }=0.980\end{array}$ \\
\hline \multicolumn{2}{|l|}{ TR1 } & & $0.711^{\mathrm{a}}$ & & 0.506 & & $\begin{array}{l}\mathrm{CFI}=0.993 \\
\mathrm{IFJ}=0.994\end{array}$ \\
\hline \multicolumn{2}{|l|}{ TR2 } & & 0.603 & 10.169 & 0.363 & & $\begin{array}{l}\mathrm{IFI}=0.994 \\
\mathrm{MFI}=0.998\end{array}$ \\
\hline \multicolumn{2}{|l|}{ TR4 } & & 0.754 & 10.648 & 0.569 & & $\begin{array}{l}\text { RMSEA }=0.041 \\
{[0.000,0.116]}\end{array}$ \\
\hline \multicolumn{2}{|l|}{ TR5 } & & 0.427 & 7.146 & 0.182 & & $\begin{array}{l}\chi^{2}=3.287 \\
\text { d.f. }=2 ; p=0.193 \\
\alpha=0.670\end{array}$ \\
\hline \multicolumn{2}{|c|}{ Application capability* } & & 0.966 & 2.483 & 0.933 & 0.671 & $\begin{array}{l}\text { BBNFI }=0.984 \\
\text { BBNNFI }=0.978\end{array}$ \\
\hline \multicolumn{2}{|c|}{ AP1 } & & $0.674^{\mathrm{a}}$ & & 0.455 & & $\begin{array}{l}\mathrm{CFI}=0.993 \\
\mathrm{IFI}=0.993\end{array}$ \\
\hline \multicolumn{3}{|l|}{$\mathrm{AP} 3$} & 0.632 & 11.2 & 0.399 & & $\begin{array}{l}\text { MFI }=0.998 \\
\text { RMSEA }=0.045\end{array}$ \\
\hline \multicolumn{3}{|l|}{ AP4 } & 0.718 & 9.975 & 0.515 & & $\begin{array}{l}\chi^{2}=3.636 ; \\
\text { d.f. }=2 ; p=0.162 \\
\alpha=0.743\end{array}$ \\
\hline \multicolumn{3}{|l|}{$\begin{array}{c}\text { Incremental } \\
\text { innovation } \\
\text { performance* }\end{array}$} & & & & 0.857 & $\begin{array}{l}\text { BBNFI }=0.993 \\
\text { BBNNFI }=0.991 \\
\text { CFI }=0.997\end{array}$ \\
\hline \multicolumn{3}{|l|}{ II1 } & $0.865^{\mathrm{a}}$ & & 0.748 & & $\mathrm{IFI}=0.997$ \\
\hline \multicolumn{3}{|l|}{ II2 } & 0.945 & 23.567 & 0.892 & & $\begin{array}{l}\text { MFI }=0.998 \\
\text { RMSEA }=0.050 \\
{[0.000,0.134]}\end{array}$ \\
\hline \multicolumn{3}{|l|}{ II3 } & 0.912 & 22.815 & 0.832 & & $\begin{array}{l}\chi^{2}=3.509 ; \\
\text { d.f. }=2 ; p=0.173 \\
\alpha=0.943\end{array}$ \\
\hline \multicolumn{3}{|l|}{$\begin{array}{c}\text { Radical } \\
\text { innovation } \\
\text { performance }\end{array}$} & & & & 0.669 & $\begin{array}{l}\text { BBNFI }=0.973 \\
\text { BBNNFI }=0.860 \\
\text { CFI }=0.977\end{array}$ \\
\hline \multicolumn{3}{|l|}{ RI1 } & $0.594^{\mathrm{a}}$ & & 0.353 & & $\mathrm{IFI}=0.977$ \\
\hline \multicolumn{3}{|l|}{ RI2 } & 0.487 & 5.244 & 0.237 & & MFI $=0.993$ \\
\hline \multicolumn{3}{|l|}{ RI3 } & 0.678 & 6.620 & 0.459 & & $\begin{array}{l}\text { RMSEA }=0.115 \\
{[0.042,0.207]}\end{array}$ \\
\hline \multicolumn{2}{|l|}{ RI4 } & & 0.738 & 6.593 & 0.545 & & $\begin{array}{l}\chi^{2}=6.207 ; \\
\text { d.f. }=2 ; p=0.013 \\
\alpha=0.711\end{array}$ \\
\hline \multicolumn{8}{|c|}{$\begin{array}{l}\text { Goodness of fit indexes of the } \\
\text { overall measurement model }^{\mathbf{d}}\end{array}$} \\
\hline RMSEA & Below 0.08 & \multicolumn{6}{|l|}{0.021} \\
\hline MFI Fit Index & Up to 0.9 & \multicolumn{6}{|l|}{0.933} \\
\hline IFI Fit Index & Up to 0.9 & \multicolumn{6}{|l|}{0.986} \\
\hline CFI Fit Index & Up to 0.9 & \multicolumn{6}{|l|}{0.986} \\
\hline \multicolumn{8}{|l|}{$\begin{array}{l}\text { BB-NNFI Fit } \\
\text { Index }\end{array}$} \\
\hline BBNFI Fit Index & Close to 0.9 & 0.900 & & & & & \\
\hline $\begin{array}{l}\text { Normed Chi } \\
\text { Square }\end{array}$ & $\begin{array}{l}\text { Between } 1 \\
\text { and } 5\end{array}$ & 1.132 & & & & & \\
\hline $\begin{array}{c}\chi^{2}=328.214 ; \\
\text { d.f. }=309 ; p=0.217\end{array}$ & & & & & & & \\
\hline
\end{tabular}

Notes:

${ }^{a}$ Parameter equal to one to determine the scale of the latent construct.

${ }^{\mathrm{b}}$ See Appendix for a full description of the items.

${ }^{\mathrm{c}}$ The $\mathrm{t}$ values over 1.645 are significant at a level of $5 \%$ (one tail).

${ }^{\mathrm{d}}$ RMSEA = Root Mean Square Error of Approximation index; MFI= McDonald's Fit Index; IFI = Incremental Fit Index; CFI = Comparative Fit Index; BB-NNFI = Bentler-Bonett Non-Normed Fit Index; NC = Normed Chi-Squared; $\alpha=$ Cronbach's alpha

${ }^{\mathrm{e}}$ The goodness of fit indexes for this individual measurement scale were calculated on the basis of the original four-item scale (see Appendix). 
Table 4. Discriminant validity of the constructs

\begin{tabular}{llrll}
\hline \multicolumn{1}{c}{ Variable } & \multicolumn{1}{c}{ Model } & $\boldsymbol{\chi}^{\mathbf{2}}$ & df & $\Delta \boldsymbol{\chi}^{\mathbf{2}}$ \\
\hline $\begin{array}{l}\text { Potential absorptive } \\
\text { capability }\end{array}$ & $\begin{array}{l}\text { 1. Unconstrained model } \\
\text { 2. Acquisition - assimilation }\end{array}$ & 18.441 & 13 & \\
\hline $\begin{array}{l}\text { Realised absorptive } \\
\text { capability }\end{array}$ & 1. Unconstrained model & 91.313 & 14 & $\overline{7} 2.872^{* *}$ \\
\hline & 2. Transformation - application & 18.734 & 13 & - \\
\hline Absorptive capability & $\begin{array}{l}\text { 1. Unconstrained model } \\
\text { 2. Potential absorptive capacity - realised } \\
\text { absorptive capacity }\end{array}$ & 87.733 & 14 & $68.999^{* *}$ \\
\hline
\end{tabular}

Notes:

$\Delta \chi^{2}=\chi^{2}$ (unconstrained model) $-\chi^{2}$ (constrained model).

$*$ p-value $<0.05, * * p$-value $<0.01$ level.

A-B implies that constructs A and B are set to be completely correlated. 
APPENDIX. SCALES AND ITEMS

\section{Section I. Internal knowledge creation capability}

When responding to the following items, consider the firm's capability to develop new knowledge through its internal resources, capabilities and systems. Evaluate the strength of the firm's competitive position for each item in relation to the direct industry competitors' average on a scale of 1 to 5 where 1 is "much worse than our competitors", 3 is "on a par with our competitors", and 5 is "much better than our competitors".

\begin{tabular}{|c|c|}
\hline & Internal knowledge creation capability \\
\hline Item & Description \\
\hline IC1 & $\begin{array}{l}\text { Degree of employees' motivation and commitment to quality and innovation at a personal level (employees' } \\
\text { commitment to innovation) }\end{array}$ \\
\hline IC2 & $\begin{array}{l}\text { Firm's capability to integrate its employees with the organisational objectives of knowledge creation and } \\
\text { learning (employees' fit with firm's learning objectives) }\end{array}$ \\
\hline IC3 & $\begin{array}{l}\text { Firm's efficiency in developing a culture and organisational systems designed to attract, develop and retain } \\
\text { talent (innovative culture and systems) }\end{array}$ \\
\hline IC4 & $\begin{array}{l}\text { Degree to which managers consider change as natural and desirable, encourage employees to learn, } \\
\text { experiment, constantly question the way things are done to improve them, solve problems and offer } \\
\text { suggestions (managerial support to learning) }\end{array}$ \\
\hline IC5 & $\begin{array}{l}\text { Degree to which the organisation stimulates the development of capabilities and knowledge sharing among } \\
\text { employees by encouraging horizontal and vertical communication, and the development of work teams and } \\
\text { discussion forums (organisational design for learning) }\end{array}$ \\
\hline IC6 & Firm's capability to efficiently assign resources to the R\&D department (R\&D investment) \\
\hline
\end{tabular}




\section{Section II. Absorptive capability}

When responding to the following items, consider the firm's capability to absorb external knowledge. Evaluate the strength of the firm's competitive position for each item in relation to the direct industry competitors" average on a scale of 1 to 5 where 1 is "much worse than our competitors", 3 is "on a par with our competitors", and 5 is "much better than our competitors".

\begin{tabular}{|c|c|}
\hline & Absorptive capability \\
\hline Item & Description \\
\hline & A) Potential Absorptive Capability (PACAP) \\
\hline $\mathrm{AC} 1$ & $\begin{array}{l}\text { Degree of management orientation of waiting to see what happens, instead of concern and orientation } \\
\text { towards the environment to monitor a wide-range of trends continuously and to discover new opportunities to } \\
\text { be exploited proactively (management's orientation towards external learning)* }\end{array}$ \\
\hline $\mathrm{AC} 2$ & $\begin{array}{l}\text { Frequency and importance of co-operation with R\&D organisations -universities, business schools, } \\
\text { technological institutes, etc. - as a member or sponsor to create knowledge and innovations (R\&D } \\
\text { cooperation) }\end{array}$ \\
\hline $\mathrm{AC} 3$ & $\begin{array}{l}\text { Firm's capability to capture relevant, continuous and up-to-date information and knowledge on current and } \\
\text { potential competitors (knowledge of the competition) }\end{array}$ \\
\hline $\mathrm{AC} 4$ & $\begin{array}{l}\text { Firm's effectiveness in establishing programmes oriented towards the internal development of technological } \\
\text { acquisition of competencies from R\&D centres, suppliers or customers (technological competences } \\
\text { acquisition capability) } \\
\text { Assimilation Capability }\end{array}$ \\
\hline AS1 & $\begin{array}{l}\text { Firm benefits from assimilating the basic, key business knowledge and technologies from the successful } \\
\text { experiences of enterprises in the same industry (industrial benchmarking) }\end{array}$ \\
\hline AS2 & $\begin{array}{l}\text { Firm's capability to assimilate new technologies and innovations that are useful or have proven potential } \\
\text { (technology assimilation capability) }\end{array}$ \\
\hline AS3 & $\begin{array}{l}\text { Firm's ability to use employees' knowledge, experience and competency in the assimilation and } \\
\text { interpretation of new knowledge (knowledge assimilation capability by human resources }\end{array}$ \\
\hline AS4 & $\begin{array}{l}\text { Degree to which company employees attend and present papers at scientific conferences and lecture at } \\
\text { universities, and other companies' employees visit the company on research assignments (involvement in } \\
\text { knowledge diffusion flows) } \dagger\end{array}$ \\
\hline AS5 & $\begin{array}{l}\text { Firm's employees attendance at training courses, trade fairs, exhibitions and meetings (knowledge absorption } \\
\text { from formal and informal professional sources) } \dagger\end{array}$ \\
\hline AS6 & $\begin{array}{l}\text { Firm's ability to develop knowledge management programmes guaranteeing employee's capability to } \\
\text { understand and carefully analyse knowledge and technology from other organisations (external knowledge } \\
\text { management) }\end{array}$ \\
\hline
\end{tabular}

Transformation Capability ${ }^{\text {a }}$

TR1 Firm's capability to use information technologies in order to improve information flow, develop the effective sharing of knowledge and foster communication between members of the firm, including virtual meetings between professionals who are physically separated via Internet B2E portals, e-mail, teleworking, etc. (transmission of IT- based knowledge)

TR2 Degree to which firm prevents all employees from voluntarily transmiting acquired scientific and technological information to each other (exchange of scientific and technological information)*

TR3 Firm's capability to adapt technologies designed by others to its particular needs (knowledge adaptation capability) $\dagger$

TR4 Awareness by the firm of its competencies in innovation, especially with respect to key technologies, and capability to eliminate obsolete internal knowledge, stimulating in exchange the search for alternative innovations and their adaptation (knowledge renewal capability)

TR5 Firm's capability to co-ordinate and integrate all phases of the R\&D process and its inter-relationships with the functional tasks of engineering, production and marketing (integration of R\&D) Application Capability

AP1 Degree of application of knowledge and experience acquired in the technological and business fields to the firm's strategy that enables it to stay at the technological leading edge in the business (knowledge application capability)

AP2 Organisation's capability to use and exploit new knowledge in the workplace to respond quickly to environment changes (new knowledge exploitation capability) $\dagger$

AP3 Firm's capability to put technological knowledge into product and process patents (patents development capability)

AP4 Firm's capability to respond to the requirements of market demand or competitive pressure, rather than innovating to gain competitiveness by broadening the portfolio of new products, capabilities and technology ideas (response to market)*

* Items are reverse scored

$\uparrow$ Item dropped from the final scale 


\section{Section III. Incremental innovation performance}

When responding to the following items, consider the firm's improvement of existing products, processes, technologies, and organisational structures, strategic orientations and management methods. Evaluate the introduction of improvements and incremental changes for each item in relation to the direct industry competitors' average on a scale of 1 to 5 where 1 is "much worse than our competitors", 3 is "on a par with competitors", and 5 is "much better than our competitors".

\begin{tabular}{ll}
\hline & \multicolumn{1}{c}{ Incremental innovation performance } \\
\hline Item & Description \\
\hline II1 & Incremental innovation of products \\
II2 & Incremental innovation of processes \\
II3 & Incremental innovation of technologies \\
II4 & Incremental innovation of organisational structures, strategic orientations and management methods $\dagger$ \\
\hline$\dagger$ Item dropped from the final scale
\end{tabular}

\section{Section IV. Radical innovation performance}

When responding to the following items, consider the firm's introduction/obtaining of new products, processes, technologies and organisational structures, strategic orientations and management methods. Evaluate the introduction of new changes for each item in relation to the direct industry competitors' average on a scale of 1 to 5 where 1 is "much worse than our competitors", 3 is "on a par with competitors", and 5 is "much better than our competitors".

\begin{tabular}{ll}
\hline & \multicolumn{1}{c}{ Radical innovation performance } \\
\hline Item & Description \\
\hline RI1 & Radical innovation of products \\
RI2 & Radical innovation of processes \\
RI3 & Radical innovation of technologies \\
RI4 & Radical innovation of organisational structures, strategic orientations and management methods \\
\hline
\end{tabular}

